\title{
Sodium Batteries: A Review on Sodium-Sulfur and Sodium-Air Batteries
}

\author{
Neha Chawla ${ }^{1, *,+}$ and Meer Safa ${ }^{2,+}+$ (D) \\ 1 Environmental Health and Safety Department, Carnegie Mellon University, Pittsburgh, PA 15213, USA \\ 2 Mechanical and Materials Engineering Department, Florida International University, Miami, FL 33174, USA; \\ msafa002@fiu.edu \\ * Correspondence: nehac@andrew.cmu.edu; Tel.: +1-412-268-3221 \\ + These authors contributed equally to this work.
}

Received: 28 September 2019; Accepted: 21 October 2019; Published: 22 October 2019

check for updates

\begin{abstract}
Lithium-ion batteries are currently used for various applications since they are lightweight, stable, and flexible. With the increased demand for portable electronics and electric vehicles, it has become necessary to develop newer, smaller, and lighter batteries with increased cycle life, high energy density, and overall better battery performance. Since the sources of lithium are limited and also because of the high cost of the metal, it is necessary to find alternatives. Sodium batteries have shown great potential, and hence several researchers are working on improving the battery performance of the various sodium batteries. This paper is a brief review of the current research in sodium-sulfur and sodium-air batteries.
\end{abstract}

Keywords: sodium-sulfur battery; sodium-air battery; battery chemistries; catalysts; cathodes

\section{Introduction}

Energy storage has become one of the major global concerns as the world is preparing to find an alternative to fossil fuels for storage and energy generation. Lithium-ion based batteries are already established as an alternative energy source to fossil fuels. They are the most common type of rechargeable batteries that can be found in almost all the portable devices to electric vehicles (EVs) [1-4]. Lithium metal is the lightest metal with a small ionic radius and has a very low redox potential of $-3.04 \mathrm{~V}$ against hydrogen electrode. The above properties enable batteries with higher voltage and energy densities. Furthermore, the small ionic radius helps ions to diffuse in solids. Higher capacity, longer cycle life, and higher rate capability make lithium-ion batteries a perfect fit for portable electronics and electric vehicles.

The demand for lithium-ion batteries is increasing rapidly because of the increased use of portable electronics and the growing future use of EVs. Several developed countries are going to ban fossil fuel-driven vehicles, so the demand for lithium metal will increase rapidly, and the metal is not abundant in nature, so there is a possibility of the prices to go up sharply in the next few decades [5,6]. Hence research has been going on to find an alternative to lithium for future generation energy storage devices. Sodium is an alternate choice for lithium as the metal is abundant in nature, which will make batteries cheaper, is the second lightest material next to lithium, and its redox potential is $-2.7 \mathrm{~V}$ against hydrogen electrode, which is slightly higher than lithium.

The application of RT Na/S battery, however, faces some critical challenges of low cyclic stability and rapid capacity fading in the first few cycles, which is similar to Li-S battery systems because of the polysulfide shuttle effect during the charge-discharge process. Unfortunately, the problem in Na-S battery is more serious than the Li-S system. In this review article, we discuss the recent development beyond sodium-ion batteries, focusing on room temperature sodium-sulfur (RT Na-S) 
and sodium-air/ $\mathrm{O}_{2}$ batteries. The article first introduces the principles of charge/discharge mechanisms of RT Na-S and Na-air/ $\mathrm{O}_{2}$ batteries, followed by a summary of the recent progress in research.

\section{Sodium Sulfur Battery}

Sulfur as cathode materials possesses a high discharge capacity of $1675 \mathrm{mAh} \mathrm{g}^{-1}$ which is one order of magnitudes compared to the insertion-cathode system. This high capacity makes this material a serious candidate for the future generation battery system. In 2006, room temperate sodium-sulfur (Na-S) battery was reported for the first time [7]. Since then several researches have been conducted to improve the electrochemical utilization of the active sulfur material and its cyclic performance for longer cycles [8]. The principle mechanism and the selection of $\mathrm{Na}-\mathrm{S}$ battery electrodes are similar to Li-S battery technology. The most common Na-S cell consists of Na metal as anode, sulfur-carbon composite as cathode, and organic liquids as electrolyte. During the discharge process the anode sodium metal gets oxidized and forms sodium ions and electrons. The ion moves through the electrolyte and separator to reach the sulfur composite cathode, while the electrons move to the cathode through the external circuit and generate electricity. Meanwhile, on the cathode, sulfur gets reduced by accepting the sodium ions, and the electrons thus form complex sodium polysulfides. The typical charge-discharge cut-off voltage for Na-S cell is from 1 to $3 \mathrm{~V}$. The charge-discharge of Na-S cell shows a series of complicated formation of long-chain $\left(\mathrm{Na}_{2} \mathrm{~S}_{\mathrm{n}}, 4 \leq \mathrm{n} \leq 8\right)$ and short-chain $\left(\mathrm{Na}_{2} \mathrm{~S}_{\mathrm{n}}, 1 \leq \mathrm{n}<4\right)$ polysulfides similar to Li-S cells $[9,10]$. Figure $1 \mathrm{~b}$ shows a typical discharge voltage profile of a Na-S battery. The figure shows two plateaus at $\sim 2.2 \mathrm{~V}$ and $\sim 1.65 \mathrm{~V}$ during discharge, and at charging the plateaus are at $\sim 1.75 \mathrm{~V}$ and $\sim 2.4 \mathrm{~V}$. The discharge curve in the figure is divided into four stages. On the first stage, elemental sulfur gets reduced to long-chain sodium polysulfides, where a solid to liquid transition occurs at $\approx 2.2 \mathrm{~V}$ :

$$
\mathrm{S}_{8}+2 \mathrm{Na}^{+}+2 \mathrm{e}^{-} \rightarrow \mathrm{Na}_{2} \mathrm{~S}_{8}
$$

Stage 2 represents the sloping line in the voltage range from $2.2 \mathrm{~V}$ to $1.65 \mathrm{~V}$, where a liquid to liquid transition from $\mathrm{Na}_{2} \mathrm{~S}_{8}$ to $\mathrm{Na}_{2} \mathrm{~S}_{4}$ occurs:

$$
\mathrm{Na}_{2} \mathrm{~S}_{8}+2 \mathrm{Na}^{+}+2 \mathrm{e}^{-} \rightarrow 2 \mathrm{Na}_{2} \mathrm{~S}_{4}
$$

In stage 3 , a low-voltage plateau at $\approx 1.65 \mathrm{~V}$ can be seen because of a liquid to solid transition where $\mathrm{Na}_{2} \mathrm{~S}_{4}$ is reduced to short-chain insoluble $\mathrm{Na}_{2} \mathrm{~S}_{3}, \mathrm{Na}_{2} \mathrm{~S}_{2}$, or $\mathrm{Na}_{2} \mathrm{~S}$ :

$$
\begin{gathered}
\mathrm{Na}_{2} \mathrm{~S}_{4}+\frac{2}{3} \mathrm{Na}^{+}+\frac{2}{3} \mathrm{e}^{-} \rightarrow \frac{4}{3} \mathrm{Na}_{2} \mathrm{~S}_{3} \\
\mathrm{Na}_{2} \mathrm{~S}_{4}+2 \mathrm{Na}^{+}+2 \mathrm{e}^{-} \rightarrow 2 \mathrm{Na}_{2} \mathrm{~S}_{2} \\
\mathrm{Na}_{2} \mathrm{~S}_{4}+6 \mathrm{Na}^{+}+6 \mathrm{e}^{-} \rightarrow 2 \mathrm{Na}_{2} \mathrm{~S}
\end{gathered}
$$

In the last stage, a second sloping line in the voltage range from $1.65 \mathrm{~V}$ to $1.2 \mathrm{~V}$ corresponding to a solid-solid reaction by the reduction reaction of $\mathrm{Na}_{2} \mathrm{~S}_{2}$ to $\mathrm{Na}_{2} \mathrm{~S}$ :

$$
\mathrm{Na}_{2} \mathrm{~S}_{2}+2 \mathrm{Na}^{+}+2 \mathrm{e}^{-} \rightarrow 2 \mathrm{Na}_{2} \mathrm{~S}
$$

Stage 2 is the most complicated reaction step compared to the other stages as it is dominated by the presence of multiple polysulfide species in the solution. In stage 3 , the reaction competition between the reactions 3 to 5 determines the discharge voltage and the capacity of the stage. Stage 4 is kinetically the slowest among the others and shows high polarization because of the non-conductive nature of the short-chain $\mathrm{Na}_{2} \mathrm{~S}_{2}$ and $\mathrm{Na}_{2} \mathrm{~S}$ formation. 
a

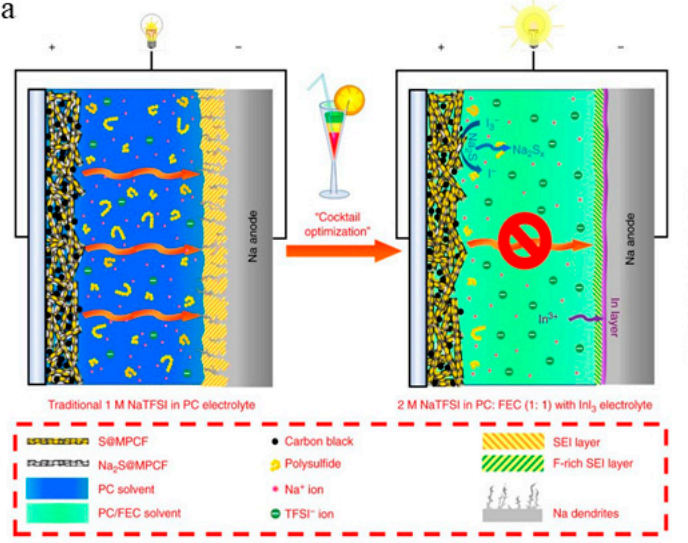

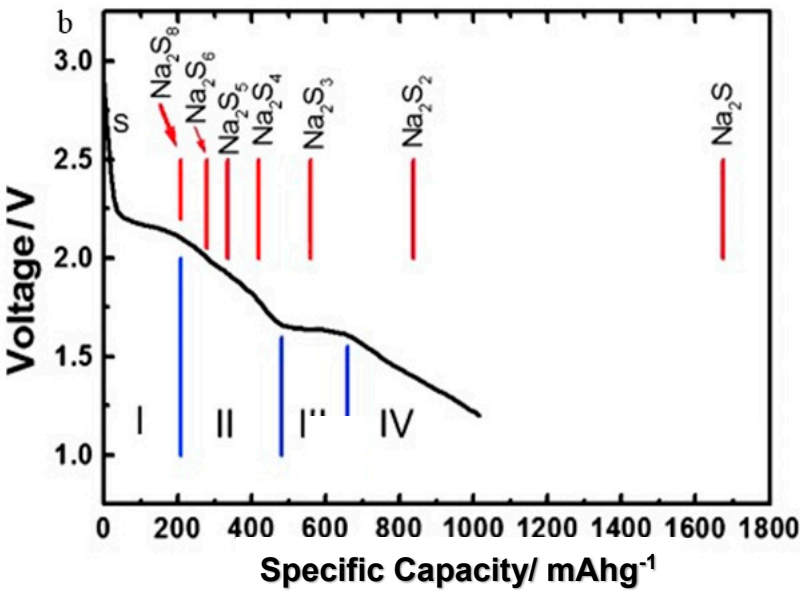

Figure 1. (a) Schematic illustration of RT -Na/S batteries [11] (b) Reaction stages during discharge for RT-Na/S batteries [8]. Reprinted with permission from Wiley, copyright 2019.

\subsection{Technical Challenges}

Although sulfur cathode-based batteries possess high theoretical capacity, there are some technical challenges for Na-S batteries coming from the materials chemistry and the system of the battery $[12,13]$. The common problems are the same as of Li-S batteries. The extremely low conductivity of sulfur $\left(\approx 10^{-30} \mathrm{~S} \mathrm{~cm}^{-1}\right)$, the low reactivity between sulfur and sodium, the formation of intermediate polysulfide during the discharge process makes unstable electrochemical contact, and the gradual increase in impedances because of the formation of passivation layers on the electrodes during cycling makes it difficult to reach high theoretical capacity. Although RT Na-S batteries have similar problems like Li-S batteries, the concerns are greater for Na-S batteries because of the sluggish nature of the electrolyte and rapid polysulfide migration during cycling, which makes the application of RT Na-S batteries more challenging.

So far, several types of research have been going on to overcome the challenges for RT Na-S batteries. Most of the researches are focusing on the sulfur-containing cathode to improve the reaction kinetics of the cathode; lower the shuttle effect, and improve the performance of the RT Na-S batteries at room temperature. Other researches also focused on the application of solid-state electrolyte, which improved the interfacial contact between electrode-electrolyte interfaces, thus reduced the $\mathrm{Na}$ dendrite formation. The following sections will highlight the recent progress on the electrode and electrolyte materials that are used to improve the performance of RT Na-S batteries.

\subsection{Cathodes}

As it is discussed earlier that the two major drawbacks in RT-Na-S battery system are the insulating nature of the active material sulfur and the shuttle effect because of the formation of polysulfides during cycling, which gives poor cyclic stability of the battery system. A large number of researches are going on to improve the conductivity of the cathode system by mixing or embedding or encapsulating sulfur in a conducting agent like carbon or polymers. The list of the research in RT Na-S battery is shown in Table 1, which summarizes the cathode, electrolyte materials that are used in the battery, and the cyclic performances at the first cycle and at the longest cycles at a certain current density.

At the early stages of research, sulfur was mixed with carbon in a ball mill for a proper mixing of sulfur and carbon, which created a conductive framework to enhance the utilization of active sulfur. Acetylene carbon black and super P were mostly used as a source of conductive agents. Park et al., for the first time reported this improvement by mixing $70 \mathrm{wt} \% \mathrm{~S}$ with $20 \mathrm{wt} \% \mathrm{C}$ in $10 \mathrm{wt} \%$ polyethylene oxide (PEO) binder and a solid electrolyte with an initial discharge capacity of $505 \mathrm{mAh} \mathrm{g}^{-1}$ at $90^{\circ} \mathrm{C}$. However, a rapid capacity drop was observed in just after 10 cycles to only $166 \mathrm{mAh} \mathrm{g}^{-1}$ [14]. An increase in carbon content to $40 \mathrm{wt} \%$ was reported by Wenzel et al. with an initial discharge capacity of $\sim 475 \mathrm{mAhg}^{-1}$ 
and enhanced cyclic stability to 40 cycles at room temperature using beta alumina solid electrolyte [15]. Although the mechanical mixing of sulfur, carbon, and binder is an easier approach to resolve the conductivity issue of the electrode system, more research was needed to improve the cyclic stability. Low sulfur content creates poor contact between $S$ and C, while high sulfur content creates sulfur agglomerates on the carbon particles and results in poor electrochemical performances.

Table 1. Literature review of components and performance of various Na-sulfur batteries.

\begin{tabular}{|c|c|c|c|c|c|}
\hline Cathode & Electrolyte & Current Rate & $\begin{array}{l}\text { Capacity at cycle } \\
1 / \mathrm{mAh}^{-1}\end{array}$ & $\begin{array}{l}\text { Capacity/mAh g-1 } \\
\text { after (n) cycles }\end{array}$ & Ref \\
\hline Sulfurized PAN (S-PAN) & $\begin{array}{l}1 \mathrm{M} \mathrm{NaClO}_{4} \text { in } \\
\mathrm{EC}-\mathrm{DMC}\end{array}$ & $0.1 \mathrm{~mA} \mathrm{~cm}^{-2}$ & 654.8 & $500(18)$ & [12] \\
\hline $\begin{array}{l}\text { Sulfurized PAN nanofiber } \\
\text { Sulfur } 41 w t \%\end{array}$ & $\begin{array}{l}1 \mathrm{M} \mathrm{NaPF}_{6} \text { in } 1: 1 \\
\text { EC:DMC }\end{array}$ & $0.1 \mathrm{C}$ & 756 & $648(200)$ & [16] \\
\hline Sulfurized CNF & $\begin{array}{l}\text { Polymer with intrinsic } \\
\text { porosity(PIN) coated } \\
\text { on Na3Zr2Si2PO12 }\end{array}$ & $\mathrm{C} / 5$ & $\sim 650$ & $550(100)$ & [17] \\
\hline $\begin{array}{l}\text { Polyacrylonitrile (PAN): } \\
\text { S 1:8 }\end{array}$ & $\begin{array}{l}\text { 2M NaTFSI/TMP } \\
\text { in FEC }\end{array}$ & $1 C$ & $\sim 1000$ & $788(300)$ & [18] \\
\hline C-PANS: Super P: PVDF & $\begin{array}{c}0.8 \mathrm{M} \mathrm{NaClO}_{4} \text { in } \\
\mathrm{EC} / \mathrm{EMC}^{-}\end{array}$ & $220 \mathrm{~mA} \mathrm{~g}^{-1}$ & 364 & $150(500)$ & [19] \\
\hline $\begin{array}{l}\text { S@Con-HC: Carbon Black: } \\
\text { Carboxymethyl cellulose } \\
\text { (CMC) 70:10:20 }\end{array}$ & $\begin{array}{l}1 \mathrm{M} \mathrm{NaClO} \mathrm{N}_{4} \text { in } \mathrm{PC} / \mathrm{EC} \\
\quad+5 \mathrm{wt} \% \mathrm{FEC}\end{array}$ & $100 \mathrm{~mA} \mathrm{~g}^{-1}$ & 1081 & $508(600)$ & [20] \\
\hline $\begin{array}{l}\text { Sulfur nanoparticles: } \\
\text { Super P: PVDF 60:30:10 } \\
\text { soaked carbon fiber } \\
\text { composites (CFC) }\end{array}$ & $\begin{array}{l}1.5 \mathrm{M} \mathrm{NaClO}_{4} \& 0.2 \mathrm{M} \\
\mathrm{NaNO}_{3} \text { in } \mathrm{TEGDME}\end{array}$ & $0.1 \mathrm{C}$ & 390 & $120(300)$ & [21] \\
\hline $\begin{array}{l}\text { Multiporous carbon fibers } \\
\text { (MPCFs): Super-P: Sodium } \\
\text { carboxymethyl cellulose } \\
\text { (CMCNa) 80:10:10 }\end{array}$ & $\begin{array}{l}\text { 2M NaTFSI in } \\
\text { TEGDME and PC:FEC } \\
(1: 1 \mathrm{vol}) \text { as co-solvent }\end{array}$ & $0.1 \mathrm{C}$ & 1635 & $1134(50)$ & [11] \\
\hline $\begin{array}{l}\text { rGO/S/MnxOy@SA-PANI } \\
\text { (Na Alginate/polyaniline) }\end{array}$ & $\begin{array}{l}1 \mathrm{M} \mathrm{NaClO}_{4} \text { with } 0.2 \mathrm{M} \\
\mathrm{NaNO}_{3} \text { in TEGDME }\end{array}$ & $0.2 \mathrm{Ag}^{-1}$ & 631 & $535(50)$ & [22] \\
\hline $\begin{array}{l}\text { S/CNT@MPC: Super } \\
\text { P: PVDF }\end{array}$ & $1 \mathrm{M} \mathrm{NaClO}_{4}$ in $\mathrm{PC} / \mathrm{EC}$ & $3.34 \mathrm{Ag}^{-1}$ & 1610 & $500(200)$ & [23] \\
\hline S-hollow C: Carbon: PEO & NaTFSI in TEGDME & $167 \mathrm{~mA} \mathrm{~g}^{-1}$ & 1000 & $600(20)$ & [24] \\
\hline $\begin{array}{c}\text { S@interconnected } \\
\text { mesoporous C hollow } \\
\text { spheres (iMCHS): } \\
\text { CB: CMC }\end{array}$ & $\begin{array}{c}1 \mathrm{M} \mathrm{NaClO}_{4} \text { in } \mathrm{EC} / \mathrm{PC} \\
+\mathrm{FEC}\end{array}$ & $100 \mathrm{~mA} \mathrm{~g}^{-1}$ & 328.4 & $292(200)$ & [25] \\
\hline $\begin{array}{c}\text { S/Cu-decorated } \\
\text { mesoporous C: C: CMC }\end{array}$ & $\begin{array}{l}1 \mathrm{M} \mathrm{NaClO}_{4} \text { in } \\
\mathrm{EC} / \mathrm{DMC}\end{array}$ & $50 \mathrm{~mA} \mathrm{~g}^{-1}$ & 718 & $641(110)$ & [26] \\
\hline $\begin{array}{l}\text { S/microporous C } \\
\text { polyhedron } \\
\text { composites(MCPS): } \\
\text { CB: PVDF }\end{array}$ & $1 \mathrm{M} \mathrm{NaClO}_{4}$ in $\mathrm{EC} / \mathrm{PC}$ & $84 \mathrm{~mA} \mathrm{~g}^{-1}$ & 689 & $354(100)$ & [27] \\
\hline
\end{tabular}

To overcome the above-mentioned problems, different approaches were made to prepare sulfur-based composite cathode which improved the contact between the sulfur and carbon and also the prevention of agglomeration. Wang et al. for the first time reported sulfurized composite cathode with conductive polyacrylonitrile (PAN) and achieved $654 \mathrm{mAhg}^{-1}$ at the initial cycles while maintaining stability to $500 \mathrm{mAh} \cdot \mathrm{g}^{-1}$ after 18 cycles [12]. In recent times the application of sulfurized RT Na-S batteries has been reported to have high initial discharge capacity and long cycle life [15-19], which is due to the stable atomic configuration of sulfur in the PAN matrix which helped to reduce polysulfide formation and improved kinetics of the reaction. Wu et al. recently reported improved results using PAN/S composite cathode, as shown in Figure 2. 
(a)

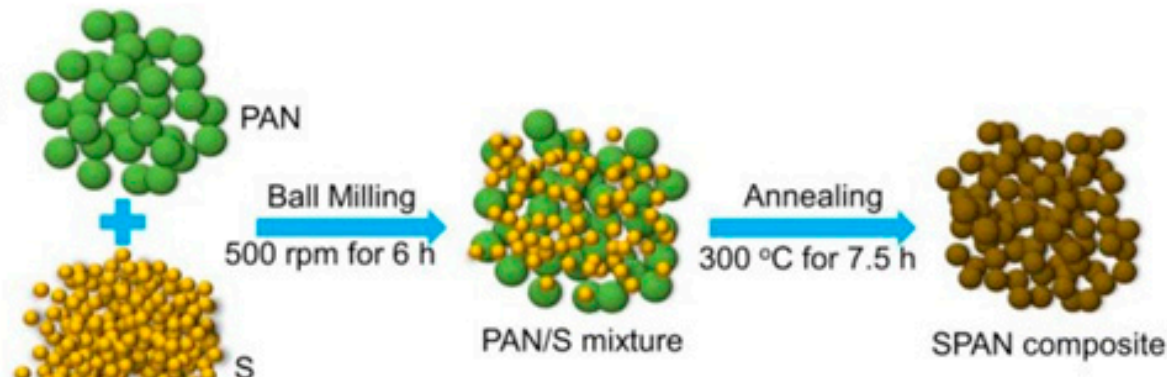

(b)

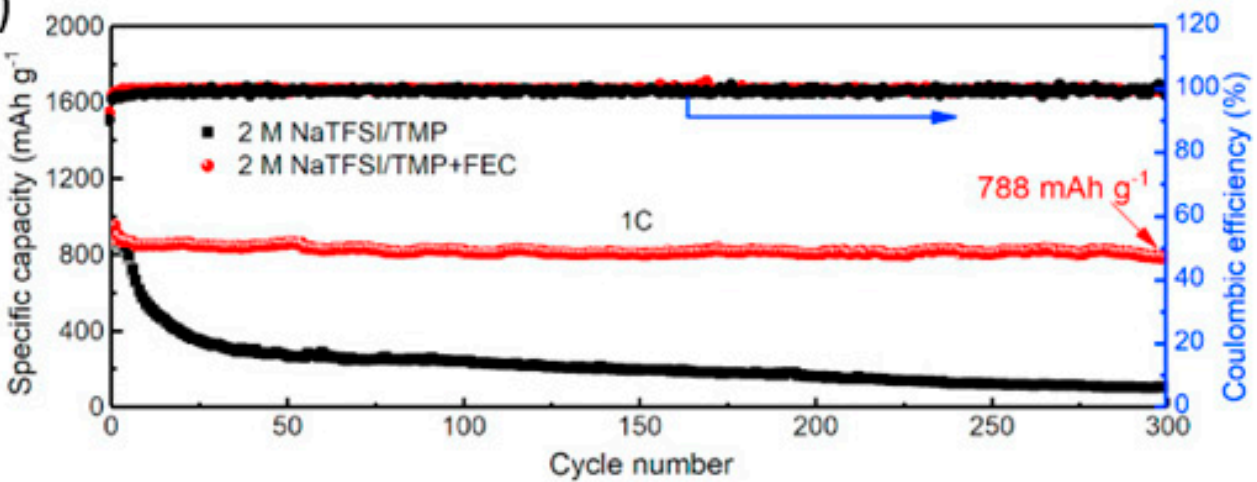

Figure 2. (a) Schematic illustration of the synthesis procedure; (b) cyclic performance of Na/Span cells with 2M NaTFSI/TMP electrolytes at 1C [18]. Reprinted with permission from Wu, J.; Liu, J.; Lu, Z.; Lin, K.; Lyu, Y.Q.; Li, B.; Ciucci, F.; Kim, J.-K.; Non-flammable electrolyte for dendrite-free sodium-sulfur battery, Elsevier, copyright 2019.

To increase the active sulfur loading, sulfur has been introduced in various forms of carbonaceous matrix framework. The most frequently used forms of carbon are CNTs, graphene, microporous, mesoporous, macroporous, and hollow carbon spheres. These types of carbons help to increase the active sulfur loading in the carbon matrix. This process also improves intimate contact between the sulfur and carbon which improves sodium ion transfer and electrolyte transport between the electrodes and thus improves the capacity and cycle life. Recently, Ghosh et al. reported $631 \mathrm{mAh} . \mathrm{g}^{-1}$ initial specific capacity using a three-dimensional ternary composite porous cathode, which is made of reduced graphene oxide ( $\mathrm{rGO}$ ), sulfur, and $\mathrm{Mn}_{\mathrm{x}} \mathrm{O}_{\mathrm{y}}$ incorporated within a $\mathrm{Na}$ alginate/polyaniline hybrid matrix as shown in Figure 3. They have concluded that the addition of $\mathrm{Mn}_{\mathrm{x}} \mathrm{O}_{\mathrm{y}}$ forms complex polythionates and acts as a mediator to anchor higher-order polysulfides and prevents polysulfide dissolution [22].

\subsection{Electrolytes}

Electrolyte soaked with a separator helps to move ions to transfer between the electrodes and prevents the short circuit by creating a barrier between the electrodes to come in contact with each other. So far various salts containing sodium and solvents based on carbonates, ethers, and ionic liquid-based have been reported in RT-Na/S battery. It has been found that the electrolyte also plays an important part in the performance of the battery alongside the cathodes. Carbonate solvents with $\mathrm{NaClO}_{4}$ salts are mostly used in RT-Na/S batteries $[11,12,19,20]$. However, the problem with this type of electrolyte is that it cannot protect the Na metal from forming dendrites, so at longer cycles and high C-rates these dendrites grow and short circuit the battery. To protect the Na metal, Zhang et al. added fluoroethylene carbonate (FEC) in the carbonate electrolyte which forms an SEI layer on the metal and improved the cyclic life of the battery. Xu et al. reported a high initial discharge capacity of $1635 \mathrm{mAh}$ $\mathrm{g}^{-1}$ at $0.1 \mathrm{C}$ rate at room temperature using multiporous carbon fibers (MPCFs), super-P conductive 
agents, and sodium carboxymethyl cellulose (CMCNa) binder [11]. They have also reported high cyclic stability of $1134 \mathrm{mAh} \mathrm{g}^{-1}$ after 50 cycles, which they attributed as the addition of InI3 additive in the carbonate electrolyte. According to their findings, InI3 acted as a redox mediator where the Na metal was protected by the formation of an indium (In) layer. This layer is formed by the $\mathrm{In}^{3+}$ redox reaction and a fluorine $\left(\mathrm{F}^{-}\right)$-rich stable SEI film. It also helped to oxidize the irreversible $\mathrm{Na}_{2} \mathrm{~S}$ during the charging process which improved the Coulombic efficiency.
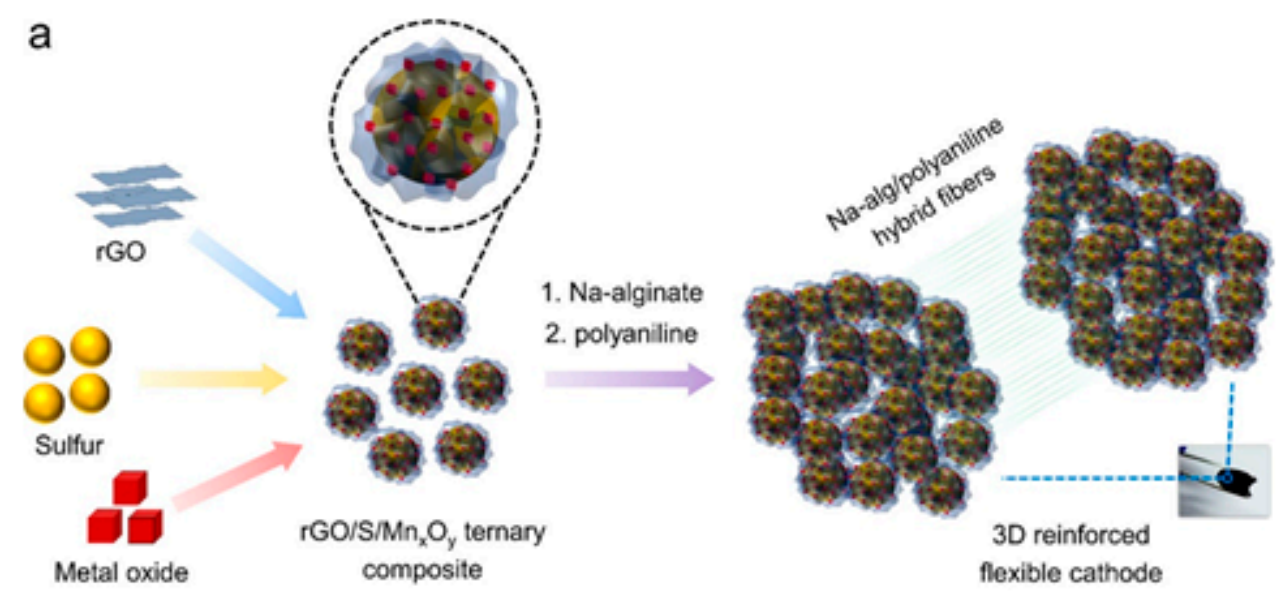

b
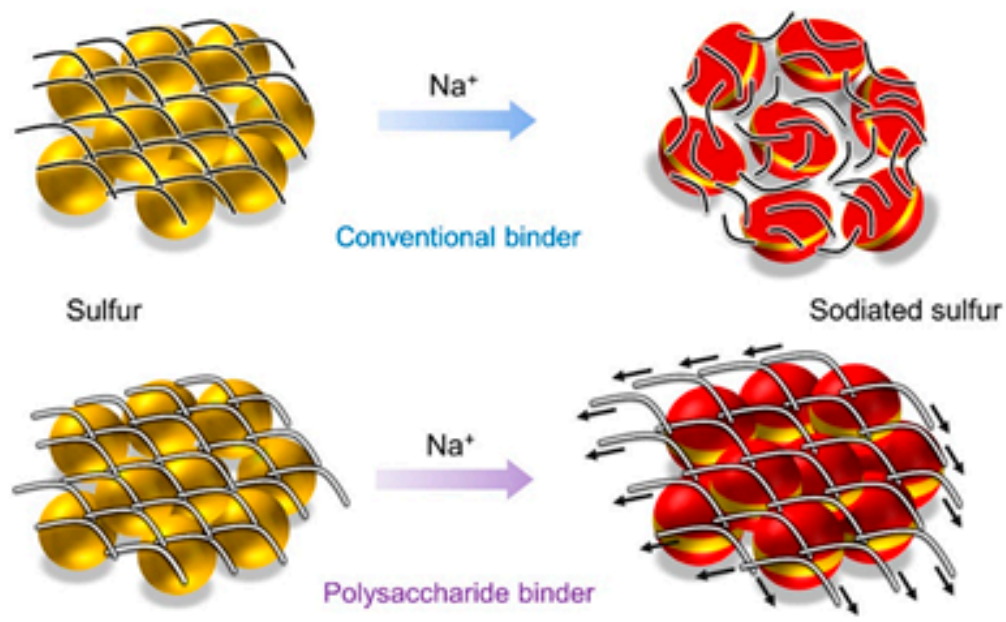

Figure 3. Schematic illustration of freestanding cathode synthesis and the role of the binder. (a) Schematic illustration of the free-standing cathode preparation. (b) Schematic of the proposed role of the polysaccharide binder to counteract volume expansion of sulfur during sodium-ion insertion [22]. Reprinted with permission from Ghosh, A.; Kumar, A.; Roy, A.; Panda, M.R.; Kar, M.; MacFarlane, D.R.; Mitra, S. Three-Dimensionally Reinforced Freestanding Cathode for High-Energy Room-Temperature Sodium-Sulfur Batteries. Copyright 2019, American Chemical Society.

Various ether-based electrolytes have been investigated in RT-Na/S batteries to overcome the shuttling effect. Long-chain ethers such as glyme-based tetraethylene glycol dimethyl ether (TEGDME) showed much-improved performance in this type of battery system because of its better solvation of oxygen atoms in the glyme structure which gives higher dissociation of sodium salts and polysulfide compounds. It has also been reported that the addition of $0.1 \mathrm{M} \mathrm{NaNO}_{3}$ in the TEGDME and $\mathrm{NaClO}_{4}$ electrolyte forms a protective SEI layer on the Na metal and improves the cyclic stability of the battery [28]. In a recent study, it has been reported that $0.1 \mathrm{M} \mathrm{NaNO}_{3}$ is not sufficient to protect the Na metal completely, while the addition of $0.2 \mathrm{M} \mathrm{NaNO}_{3}$ shows complete protection of the metal and shows improved performance [22]. 
Room-temperature ionic liquids (RTIL) are salts in a molten condition where the cations and anions are bonded as a weak van der Waals force. The major advantage of RTILs is its low flammability, negligible vapor pressure, high thermal stability, moderate ionic conductivity, and wide electrochemical potential window $[29,30]$. The above-mentioned advantages make it a serious candidate in lithium-ion and sulfur battery system. It has been widely used as an electrolyte as a replacement for the conventional carbonate-based electrolyte in lithium battery applications [31-34]. RTILs have also been reported in Li-S battery application, however the capacity and cycle life was poor because of the viscous nature of the electrolyte [29,35-38]. The application of RTIL in RT-Na/S battery is very rare. So far IL added as an additive in carbonate-based electrolyte, and improved capacity and cycle life have been observed [27].

Solid polymer or gel polymer electrolyte(GPE) is another recent approach which has shown to have good interfacial contact with the electrodes and prevents dendrite growth in the metal. Recently, Yu et al. reported Nasicon $\left(\mathrm{Na}_{3} \mathrm{Zr}_{2} \mathrm{Si}_{2} \mathrm{PO}_{12}\right)$-based solid electrolyte which acted as a polysulfide shield by enhancing the interfacial properties, as shown in Figure 4 [17].

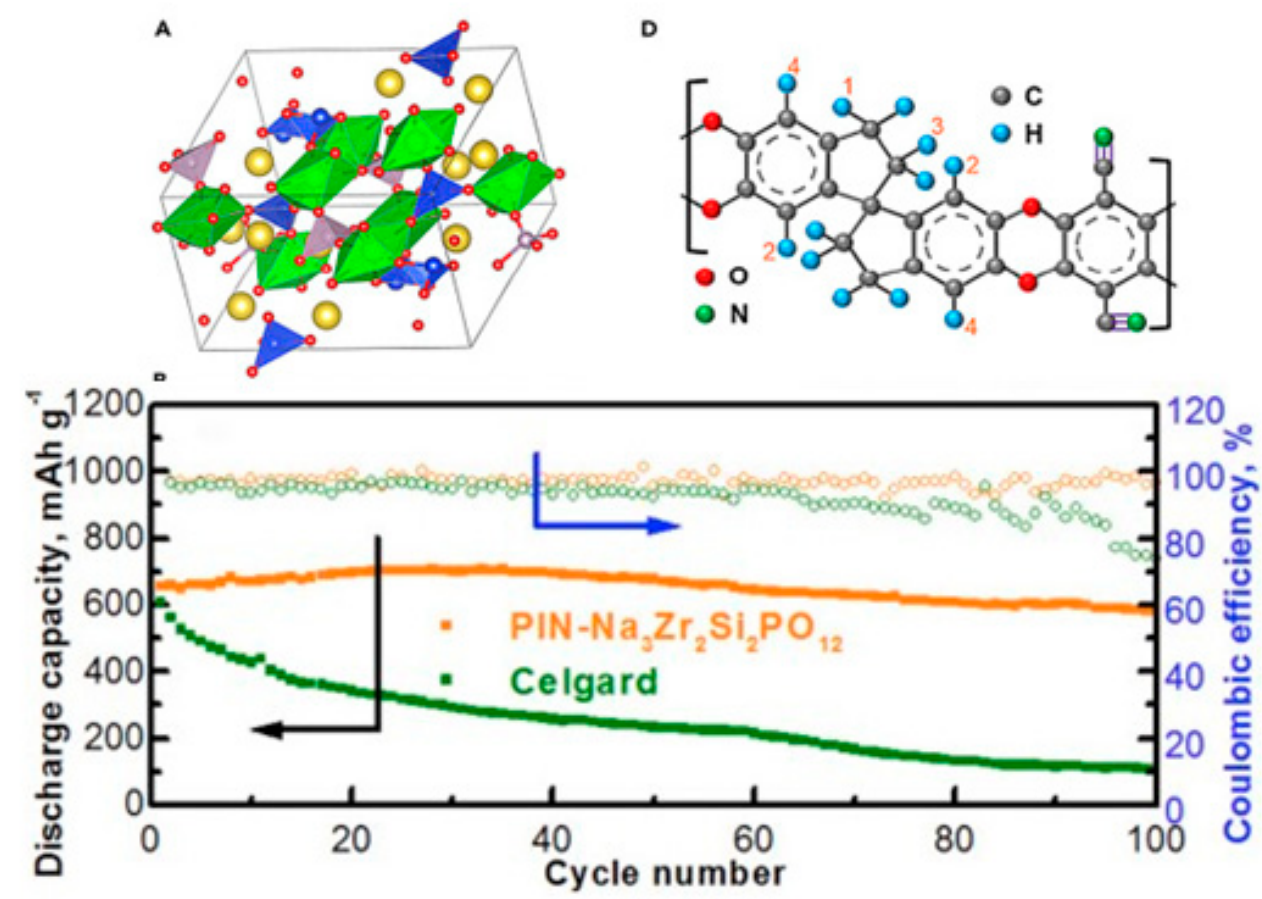

Figure 4. Illustration of the NASICON structure of $\mathrm{Na}_{3} \mathrm{Zr}_{2} \mathrm{Si}_{2} \mathrm{PO}_{12}$ material and molecular structure of a polymer with intrinsic porosity (PIN) and specific discharge capacities and Coulombic efficiencies versus cycling number of a Na || PIN [17]. Reprinted with permission from Yu, X.; Manthiram, A. Sodium-Sulfur Batteries with a Polymer-Coated NASICON-type Sodium-Ion Solid Electrolyte; copyright 2019 from Elsevier.

\section{Sodium-Air Battery}

\subsection{Introduction}

Metal-air batteries have been under investigation for many years because of their higher theoretical capacities. Most of the research has been focused on lithium-air batteries because they have the highest energy density of about $3458 \mathrm{Wh} \cdot \mathrm{kg}^{-1}$ and an overpotential of $2.96 \mathrm{~V}$ [31,39-47]. However, because of limitations including poor cyclability, large overpotential, SEI (solid electrolyte interface) layer formation [39], blockage of cathode reaction sites by electrolyte decomposition [42,44], electrolyte degradation [39], and high lithium metal cost, several other battery chemistries are being studied simultaneously. Recently, research is being conducted on sodium air, aluminum air, magnesium air, zinc-air, iron air, and tin air batteries. 
Sodium air batteries have reported promising results as an alternative metal-air battery and have gained attention as the next generation batteries because of their high specific densities and capacities. Sodium is the sixth most abundant element found on earth with an energy density of about $1600 \mathrm{Wh} \cdot \mathrm{kg}^{-1}$ [48]. The theoretical energy density and specific capacity of sodium are $3164 \mathrm{Wh} . \mathrm{kg}^{-1}$ and $1166 \mathrm{mAh} . \mathrm{g}^{-1}$, respectively. The energy cost of rechargeable Li-air batteries is $\$ 300-\$ 500 \mathrm{kWh}^{-1}$ whereas for Na-air batteries, it is $\$ 100-150 \mathrm{kWh}^{-1}$ [48]. Even though lithium and sodium are chemically close, they react very differently with oxygen. In lithium-air batteries, lithium reacts with oxygen to form $\mathrm{LiO}_{2}$ (lithium oxide) as an intermediate species before forming $\mathrm{Li}_{2} \mathrm{O}_{2}$ (lithium peroxide). $\mathrm{Li}_{2} \mathrm{O}_{2}$ deposition on the cathodes results in lower reversal of discharge products during charging. Whereas for Na-air batteries, sodium combines with oxygen to form $\mathrm{NaO}_{2}$ (sodium superoxide) which is more stable, does not decompose, and hence assists during the reversal of discharge products while charging.

Peled et al. first investigated Na-air batteries in 2011 [49]. They operated the Na-air battery at $105^{\circ} \mathrm{C}$ using liquid sodium, ETEK cathode, and polymer electrolyte. First room temperature Na-air battery was reported by Sun et al. in 2012, with 20 cycles, the discharge capacity of $1058 \mathrm{mAh} . \mathrm{g}^{-1}$, and a coulombic efficiency of $85 \%$ [50]. They confirmed the formation of the major discharge product, $\mathrm{Na}_{2} \mathrm{O}_{2}$.

A typical Na-air battery as shown in Figure 5, consists of a sodium metal anode and a porous cathode separated by a separator in the electrolyte. The batteries undergo discharge and charge processes. During discharging, sodium gets oxidized and forms sodium ions $\left(\mathrm{Na}^{+}\right)$. The cation then moves through the electrolyte to combine with the electron from the external circuit and reduces the adsorbed oxygen, thus forming $\mathrm{NaO}_{2}$ that is reversibly reduced to $\mathrm{O}_{2}$ and $\mathrm{Na}^{+}$. Na-air batteries can be classified as aprotic and aqueous/hybrid Na-air batteries [51,52]. In aprotic batteries, the insoluble and non-conductive $\mathrm{NaO}_{2}$ and $\mathrm{Na}_{2} \mathrm{O}_{2}$ (discharge products) are deposited on the porous cathode thus blocking the reaction sites. Whereas in hybrid or aqueous Na-air batteries, a Na-ion conducting NASICON-type $\left(\mathrm{Na}_{3} \mathrm{Zr}_{2} \mathrm{Si}_{2} \mathrm{PO}_{12}\right)$ separator has been used that assists in reducing the clogging of cathode pores with the discharge products $[51,53,54]$. Figure 6 shows the structure of non-aqueous and aqueous Na-air batteries with nanoporous gold electrode and their discharge-charge behavior.

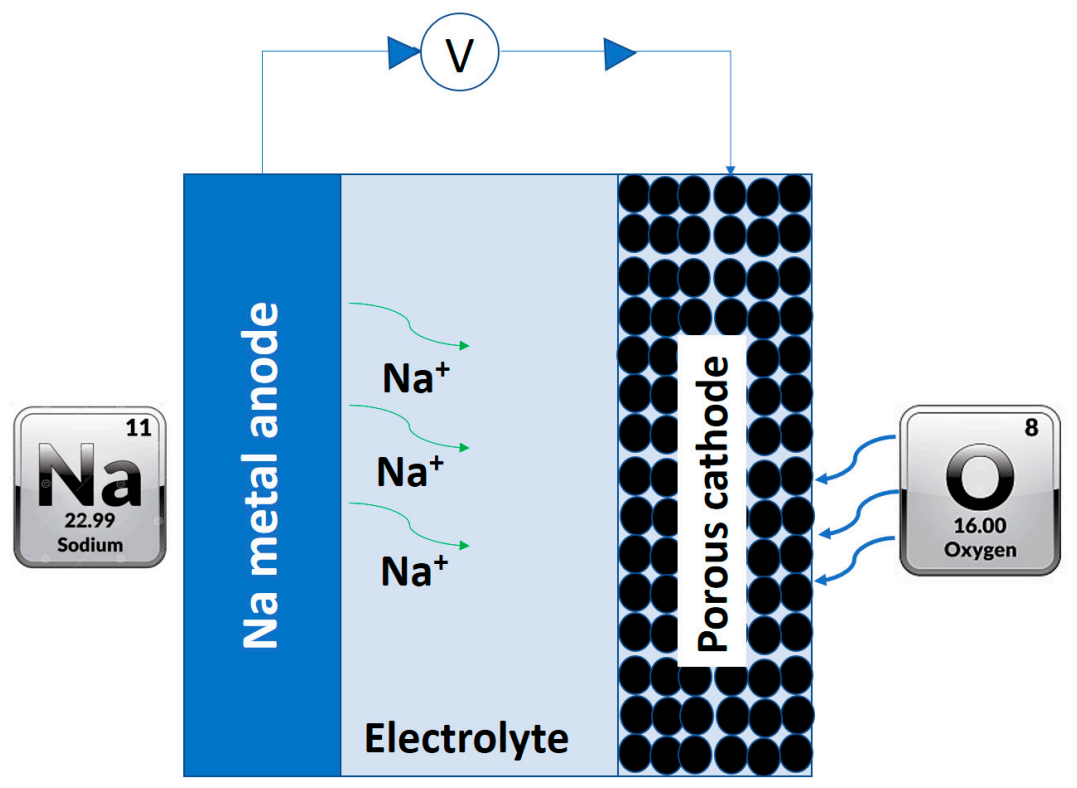

Figure 5. Schematic representation of a typical sodium-air battery.

\subsection{Electrochemical Reactions in the Na-Air Battery}

The following reactions occur during the discharge-charge process of aqueous Na-air batteries [55]: 

At cathode:
$\mathrm{O}_{2}+2 \mathrm{H}_{2} \mathrm{O}+4 \mathrm{e}^{-} \leftrightarrow 4 \mathrm{OH} ;$
$\mathrm{E}_{0}=+0.40 \mathrm{~V}$
(i)
At anode:
$\mathrm{Na} \leftrightarrow \mathrm{Na}^{+}+\mathrm{e}^{-}$;
$\mathrm{E}_{0}=+2.71 \mathrm{~V}$
Overall:
$4 \mathrm{Na}+\mathrm{O}_{2}+2 \mathrm{H}_{2} \mathrm{O} \leftrightarrow 4 \mathrm{NaOH}$;
$\mathrm{E}_{0}=3.11 \mathrm{~V}$
(iii)

The standard cell voltage based on the above equations is $3.11 \mathrm{~V}$.

However, for aprotic Na-air batteries, the reactions are given as follows [56]:

$\begin{array}{llll}\text { At Cathode: } & \mathrm{O}_{2}+\mathrm{e}^{-} \leftrightarrow \mathrm{O}_{2}^{-} ; & \mathrm{E}_{0}=-0.44 \mathrm{~V} & \text { (iv) } \\ \text { Or } & \mathrm{O}_{2}+2 \mathrm{e}^{-} \leftrightarrow \mathrm{O}_{2}{ }^{2-} ; & \mathrm{E}_{0}=0.38 \mathrm{~V} & \text { (v) } \\ \text { Anode: } & \mathrm{Na} \leftrightarrow \mathrm{Na}^{+}+\mathrm{e}^{-} ; & \mathrm{E}_{0}=+2.71 \mathrm{~V} & \text { (vi) } \\ \text { Overall: } & \mathrm{Na}+\mathrm{O}_{2} \leftrightarrow \mathrm{NaO}_{2} ; & \mathrm{E}_{0}=2.27 \mathrm{~V} & \text { (vii) } \\ \text { Or } & 2 \mathrm{Na}+\mathrm{O}_{2} \leftrightarrow \mathrm{Na}_{2} \mathrm{O}_{2} ; & \mathrm{E}_{0}=2.33 \mathrm{~V} & \text { (viii) }\end{array}$

(a) Nonaqueous $\mathrm{Na}-\mathrm{O}_{2}$

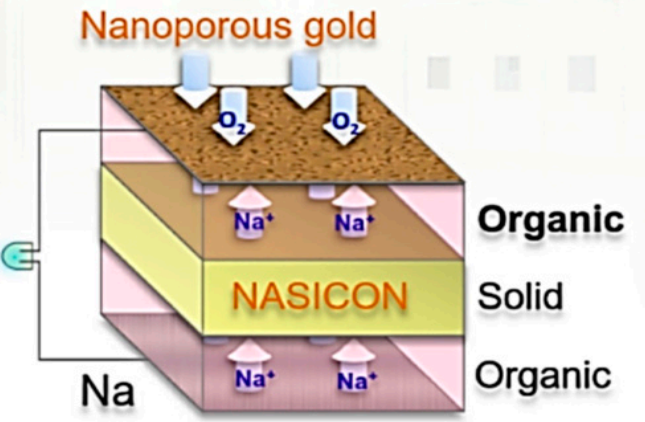

(b) Aqueous $\mathrm{Na}$ - 'air'

\section{Nanoporous gold}

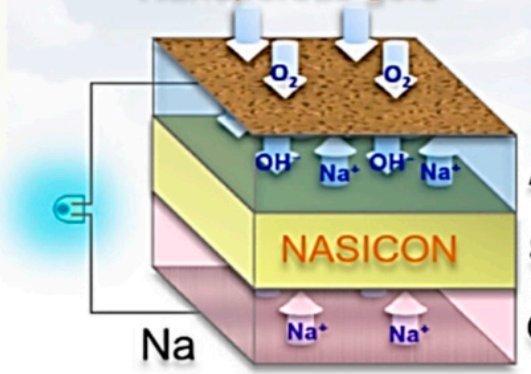

Aqueous

Solid

Organic

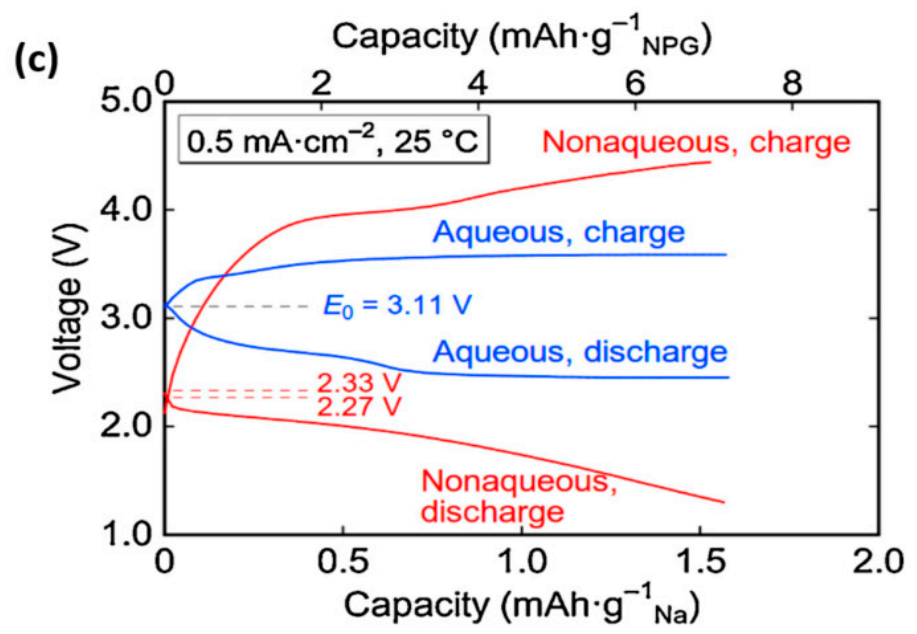

Figure 6. Schematic structure of (a) non-aqueous and (b) aqueous Na-air batteries with nanoporous gold electrode. (c) First discharge charge curves of non-aqueous and aqueous batteries at $0.5 \mathrm{~mA} \cdot \mathrm{cm}^{-2}$ up to $7 \mathrm{mAh} \cdot \mathrm{g}^{-1}$ NPG [57]. Reprinted from Aqueous and Nonaqueous Sodium-Air Cells with Nanoporous Gold Cathode, 182; Taijyu Hashimoto, Katsuro Hayashi; Copyright 2019, with permission from Elsevier.

\subsection{Components of the Na-Air Battery}

\subsubsection{Electrolytes}

To enhance Na-air battery performance, the electrolyte must be highly stable against oxygen for longer cycles and reversibility. Na-air batteries have been classified as aqueous and non-aqueous based on the electrolytes. Aqueous electrolytes assist in the prevention of deactivation of catalyst by discharge products. Anode electrolytes are commonly formed with sodium salts, namely $\mathrm{NaCF}_{3} \mathrm{SO}_{3}$ and $\mathrm{NaClO}_{4}$, in $0.1 \mathrm{M}-1 \mathrm{M}$ of organic solvents such as ethylene carbonate/dimethyl carbonate (EC/DMC) and 
tetra-ethylene glycol dimethyl ether (TEGDME) [58]. The electrolyte used significantly affects the formation of SEI film thus reducing the battery performance if the SEI film is unstable or improving the battery performance by the stable SEI film formation [59]. The influence of various sodium salts including $\mathrm{TFSi}^{-}, \mathrm{PF}_{6}{ }^{-}, \mathrm{OTf}^{-}$, and $\mathrm{ClO}_{4}{ }^{-}$on Na-air batteries was studied by Lutz et al. [59]. Figure 7 shows the effect of the different salts on the SEI formation.

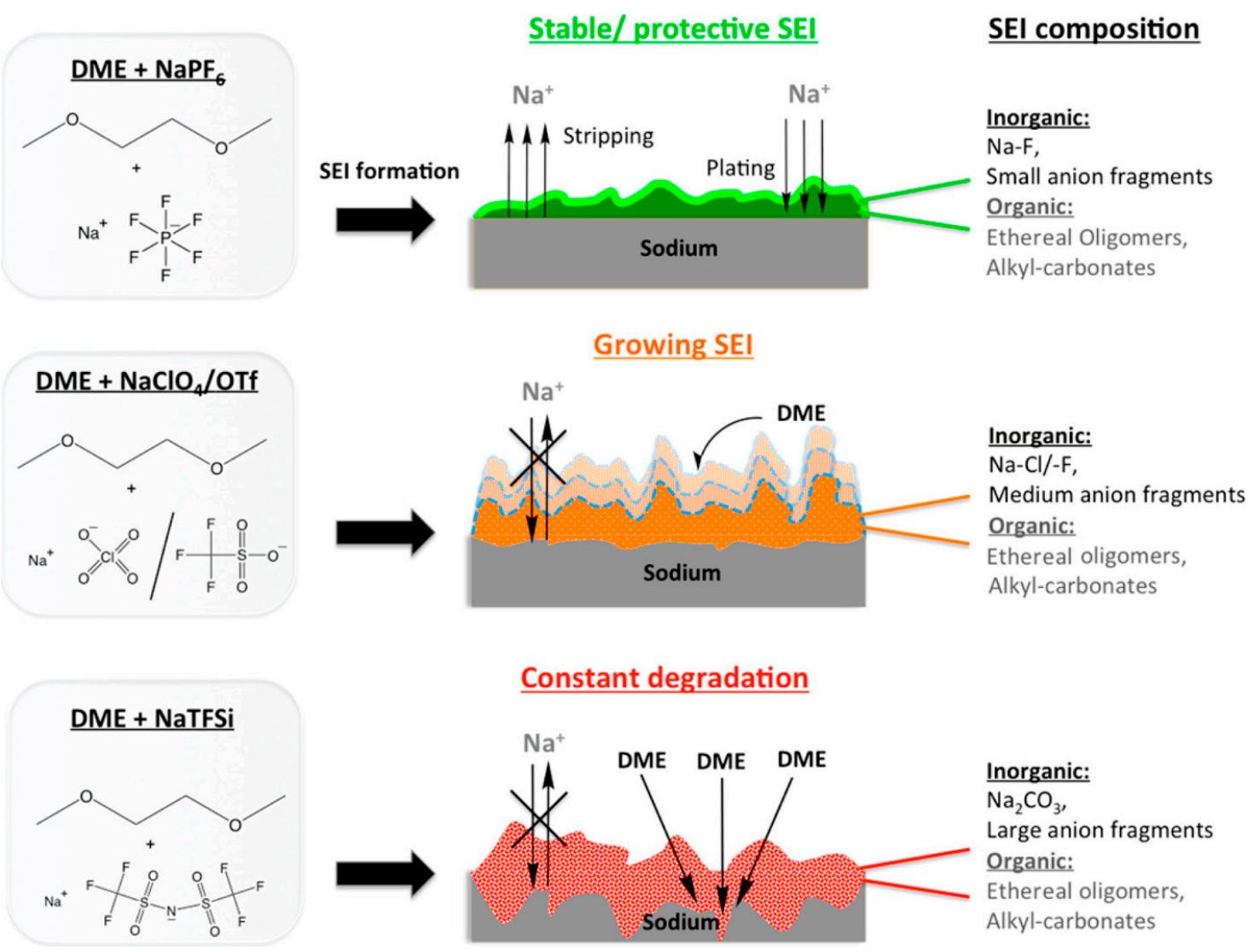

Figure 7. Illustration of the suggested sodium solid electrolyte interface (SEI) formation mechanism and its composition in different DME (1,2-dimethoxyethane) electrolytes [59]. Reprinted with permission from ACS, Copyright 2017.

\subsubsection{Separator}

Separators are inactive components used in aqueous Na-air batteries to separate the anode and cathode to prevent short circuits, to provide a path for ionic conduction, and prevent mixing of electrolytes. NASICON, sodium-ion conducting oxide ceramic with the chemical formula $\mathrm{Na}_{1+x} \mathrm{Zr}_{2} \mathrm{Si}_{\mathrm{x}} \mathrm{P}_{3-\mathrm{x}} \mathrm{O}_{12}, 0<\mathrm{x}<3[60]$ is the most commonly used separator for Na-air batteries.

\subsubsection{Cathodes and Catalysts}

The cathodes play a vital role in the electrochemical performance of the batteries. Porous carbon is a typical cathode for most of the Na-air batteries. However, the discharge products get deposited in the porous structure of the cathode, thus blocking the reaction sites which results in battery failure. Catalysts optimize battery performance by providing better-dispersed reaction sites. The comparison and performance of Na-air batteries using various cathodes, catalysts, separators, and electrolytes are shown in Table 2. Lithium metal anode was used for all the references mentioned in the table below. 
Table 2. Literature review of components and performance of various Na-air batteries. Lithium metal was the anode in all cases.

\begin{tabular}{|c|c|c|c|c|c|c|c|c|}
\hline Cathode & Catalyst & Separator & Electrolyte & Current Density & Cycles & Over-Potential (V) & $\begin{array}{l}\text { Round Trip } \\
\text { Efficiency (\%) }\end{array}$ & Ref \\
\hline Catalyst on nickel mesh & $\begin{array}{l}\text { Dual-phase spinel } \mathrm{MnCo}_{2} \mathrm{O}_{4} \text { with } \\
\text { nitrogen-doped reduced graphene } \\
\left.\text { oxide hybrid (dp-MnCo } \mathrm{On}_{4} / \mathrm{N}-\mathrm{RGO}\right)\end{array}$ & NASICON & $\begin{array}{l}1 \mathrm{M} \mathrm{NaClO}_{4} \text { in EC/DMC (1:1) with } \\
1 \mathrm{vol} \% \mathrm{FEC} \text { as anolyte. } 1 \mathrm{M} \mathrm{NaOH} \\
\text { as catholyte }\end{array}$ & $0.13 \mathrm{~mA} \cdot \mathrm{cm}^{-2}$ & 25 & 0.39 & 87.6 & [61] \\
\hline Carbon black & $\mathrm{Pt} / \mathrm{C}$ & NASICON & $\begin{array}{l}1 \mathrm{M} \mathrm{NaClO}_{4} \text { in EC/DMC (1:1) with } \\
1 \mathrm{vol} \% \mathrm{FEC} \text { as anolyte. } 1 \mathrm{M} \mathrm{NaOH} \\
\text { as catholyte }\end{array}$ & $0.13 \mathrm{~mA} \cdot \mathrm{cm}^{-2}$ & & 0.62 & - & [61] \\
\hline Catalyst on nickel mesh & $\begin{array}{l}\text { Nitrogen-doped reduced graphene } \\
\text { oxide hybrid (N-RGO) }\end{array}$ & NASICON & $\begin{array}{l}1 \mathrm{M} \mathrm{NaClO}_{4} \text { in EC/DMC (1:1) with } \\
1 \mathrm{vol} \% \mathrm{FEC} \text { as anolyte. } 1 \mathrm{M} \mathrm{NaOH} \\
\text { as catholyte }\end{array}$ & $0.13 \mathrm{~mA} \cdot \mathrm{cm}^{-2}$ & & 0.6 & - & [61] \\
\hline Catalyst on nickel mesh & $\begin{array}{l}\text { A dual-phase spinel } \mathrm{MnCo}_{2} \mathrm{O}_{4} \text { (DP- } \\
\left.\qquad \mathrm{MnCo}_{2} \mathrm{O}_{4}\right)\end{array}$ & NASICON & $\begin{array}{l}1 \mathrm{M} \mathrm{NaClO}_{4} \text { in EC/DMC (1:1) with } \\
1 \mathrm{vol} \% \mathrm{FEC} \text { as anolyte. } 1 \mathrm{M} \mathrm{NaOH} \\
\text { as catholyte }\end{array}$ & $0.13 \mathrm{~mA} \cdot \mathrm{cm}^{-2}$ & & 0.49 & - & [61] \\
\hline Carbon black & & NASICON & $\begin{array}{l}1 \mathrm{M} \mathrm{NaClO}_{4} \text { in EC/DMC (1:1) with } \\
1 \mathrm{vol} \% \mathrm{FEC} \text { as anolyte. } 1 \mathrm{M} \mathrm{NaOH} \\
\text { as catholyte }\end{array}$ & $0.13 \mathrm{~mA} \cdot \mathrm{cm}^{-2}$ & & 1.34 & - & [61] \\
\hline $\begin{array}{c}\text { 3D flower-shaped sns } 2 \\
\text { nanostructures, called as } \\
\text { nanopetals }\end{array}$ & & NASICON & $0.1 \mathrm{M} \mathrm{NaOH}$ electrolyte & $5 \mathrm{~mA} \cdot \mathrm{g}^{-1}$ & 40 & 0.52 & 83 & [62] \\
\hline $\begin{array}{c}\mathrm{Co}_{3} \mathrm{O}_{4} \text { decorated carbon } \\
\text { nanotubes }\left(\mathrm{CNT@C} \mathrm{Co}_{3} \mathrm{O}_{4}\right)\end{array}$ & $\begin{array}{l}\text { Nanostructured cobalt oxide } \\
\qquad\left(\mathrm{CO}_{3} \mathrm{O}_{4}\right)\end{array}$ & $\begin{array}{c}\text { Polypropylene } \\
\text { (PP)-based polymer }\end{array}$ & $\begin{array}{l}\mathrm{NaCF}_{3} \mathrm{SO}_{3} / \text { diethylene glycol } \\
\text { dimethyl ether (DEGDME) }\end{array}$ & $150 \mathrm{~mA} \cdot \mathrm{g}^{-1}$ & $\begin{array}{l}12 \text { cycles at a cut off of } \\
300 \text { mA.h.g }{ }^{-1} \text { capacity }\end{array}$ & 0.4 & - & [63] \\
\hline $\begin{array}{c}\mathrm{CNT} / \mathrm{Co}_{3} \mathrm{O}_{4} \text { nanocomposite } \\
\text { powders prepared by grinding } \\
\mathrm{Co}_{3} \mathrm{O}_{4} \text { nanoparticles with CNTs }\end{array}$ & $\mathrm{Co}_{3} \mathrm{O}_{4}$ & $\begin{array}{l}\text { Polypropylene } \\
\text { (PP)-based polymer }\end{array}$ & $\begin{array}{l}\mathrm{NaCF}_{3} \mathrm{SO}_{3} / \text { diethylene glycol } \\
\text { dimethyl ether (DEGDME) }\end{array}$ & $150 \mathrm{~mA} \cdot \mathrm{g}^{-1}$ & $\begin{array}{l}12 \text { cycles at a cutoff of } \\
300 \text { mA.h. } \mathrm{g}^{-1} \text { capacity }\end{array}$ & 0.4 & - & [63] \\
\hline CNT & - & $\begin{array}{c}\text { Polypropylene } \\
\text { (PP)-based polymer }\end{array}$ & $\begin{array}{l}\mathrm{NaCF}_{3} \mathrm{SO}_{3} / \text { diethylene glycol } \\
\text { dimethyl ether ((DEGDME) }\end{array}$ & $150 \mathrm{~mA} \cdot \mathrm{g}^{-1}$ & $\begin{array}{l}13 \text { cycles at a cutoff of } \\
300 \text { mA.h.g }{ }^{-1} \text { capacity }\end{array}$ & 0.6 & - & [63] \\
\hline $\begin{array}{l}\text { Catalyst on glassy carbon } \\
\text { electrode }\end{array}$ & $\begin{array}{c}\mathrm{Tl}_{2} \mathrm{Ru}_{2} \mathrm{O}_{7} \text { functionalized using } \\
\text { dihydrogen phosphate ion } \\
\left(\mathrm{P}-\mathrm{Tl}_{2} \mathrm{Ru}_{2} \mathrm{O}_{7}\right)\end{array}$ & NASICON & $\begin{array}{c}1 \mathrm{M} \mathrm{NaCF}{ }_{3} \mathrm{SO}_{3} / \mathrm{TEGDME} \\
0.1 \mathrm{M} \mathrm{KOH}\end{array}$ & $0.01 \mathrm{~mA} \cdot \mathrm{cm}^{-2}$ & 50 & 0.16 & 95 & [64] \\
\hline $\begin{array}{l}\text { Catalyst on glassy carbon } \\
\text { electrode }\end{array}$ & $\mathrm{Tl}_{2} \mathrm{Ru}_{2} \mathrm{O}_{7}$ & NASICON & $\begin{array}{c}1 \mathrm{M} \mathrm{NaCF}_{3} \mathrm{SO}_{3} / \mathrm{TEGDME}, \\
0.1 \mathrm{M} \mathrm{KOH}\end{array}$ & $0.01 \mathrm{~mA} \cdot \mathrm{cm}^{-2}$ & - & & & [64] \\
\hline $\begin{array}{l}20 \mathrm{wt} \% \text { Pt on Vulcan carbon } \\
\text { black }\end{array}$ & Platinum $(\mathrm{Pt})$ & NASICON & $\begin{array}{c}1 \mathrm{M} \mathrm{NaCF}_{3} \mathrm{SO}_{3} / \mathrm{TEGDME} \\
0.1 \mathrm{M} \mathrm{KOH}\end{array}$ & $0.01 \mathrm{~mA} \cdot \mathrm{cm}^{-2}$ & - & 0.25 & $\sim 90$ & [64] \\
\hline $20 \mathrm{wt} \%$ Ir on Vulcan & Irradium (Ir) & NASICON & $\begin{array}{c}1 \mathrm{M} \mathrm{NaCF}{ }_{3} \mathrm{SO}_{3} / \mathrm{TEGDME}, \\
0.1 \mathrm{M} \mathrm{KOH}\end{array}$ & $0.01 \mathrm{~mA} \cdot \mathrm{cm}^{-2}$ & - & 0.3 & $\sim 90$ & [64] \\
\hline Catalyst on carbon paper & Carbon black & $\begin{array}{l}\text { Solid conductor with } \\
\mathrm{Na}_{3} \mathrm{Zr}_{2} \mathrm{Si}_{2} \mathrm{PO}_{12}\end{array}$ & $\begin{array}{l}1 \mathrm{M} \mathrm{NaClO}_{4} \text { in EC/DMC (1:1) with } \\
1 \mathrm{vol} \% \text { of fluoroethylene carbonate } \\
\text { as anolyte, } 1 \mathrm{M} \mathrm{NaOH} \text { as catholyte }\end{array}$ & $0.1 \mathrm{~mA} \cdot \mathrm{cm}^{-2}$ & - & 1.05 & & [65] \\
\hline
\end{tabular}


Table 2. Cont

\begin{tabular}{|c|c|c|c|c|c|c|c|c|}
\hline Cathode & Catalyst & Separator & Electrolyte & Current Density & Cycles & Over-Potential (V) & $\begin{array}{l}\text { Round Trip } \\
\text { Efficiency (\%) }\end{array}$ & Ref \\
\hline Catalyst on carbon paper & Silver nanoparticles & $\begin{array}{l}\text { Solid conductor with } \\
\mathrm{Na}_{3} \mathrm{Zr}_{2} \mathrm{Si}_{2} \mathrm{PO}_{12}\end{array}$ & $\begin{array}{l}1 \mathrm{M} \mathrm{NaClO}_{4} \text { in EC/DMC (1:1) with } \\
1 \mathrm{vol} \% \text { of fluoroethylene carbonate } \\
\text { as anolyte, } 1 \mathrm{M} \mathrm{NaOH} \text { as catholyte }\end{array}$ & $0.1 \mathrm{~mA} \cdot \mathrm{cm}^{-2}$ & - & 0.75 & & [65] \\
\hline Catalyst on carbon paper & $\begin{array}{l}\text { Air electrode containing nickel } \\
\text { nanoparticles as catalysts }\end{array}$ & $\begin{array}{l}\text { Solid conductor with } \\
\mathrm{Na}_{3} \mathrm{Zr}_{2} \mathrm{Si}_{2} \mathrm{PO}_{12}\end{array}$ & $\begin{array}{l}1 \mathrm{M} \mathrm{NaClO}_{4} \text { in EC/DMC (1:1) with } \\
1 \mathrm{vol} \% \text { of fluoroethylene carbonate } \\
\text { as anolyte, } 1 \mathrm{M} \mathrm{NaOH} \text { as catholyte }\end{array}$ & $0.1 \mathrm{~mA} \cdot \mathrm{cm}^{-2}$ & 100 & 0.57 & $80.0 \%$ to $69.3 \%$ & [65] \\
\hline $\begin{array}{c}\mathrm{Bi}_{2} \mathrm{Ru}_{2} \mathrm{O}_{7}(90 \mathrm{wt} \%) \text { with } \\
\text { polyvinylidene fluoride }(10 \mathrm{wt} \%) \\
\text { as a binder on one side of the } \\
\text { Teflon-treated carbon paper }\end{array}$ & $\begin{array}{l}\text { Novel nanocrystalline bismuth } \\
\text { ruthenate pyrochlore oxide } \\
\left(\mathrm{Bi}_{2} \mathrm{Ru}_{2} \mathrm{O}_{7}\right) \text { as an effective oxygen } \\
\text { electrocatalyst }\end{array}$ & NASICON & $1 \mathrm{M} \mathrm{NaCF}{ }_{3} \mathrm{SO}_{3} / \mathrm{TEGDME}$ & $0.01 \mathrm{~mA} \mathrm{~cm}^{-2}$ & 50 & 0.21 & 93.58 & [66] \\
\hline $\begin{array}{c}\text { Catalyst on conductive carbon } \\
\text { powder }\end{array}$ & $\begin{array}{l}\text { Metal-organic framework-derived } \\
\text { N-doped carbon nanotubes } \\
\text { (MOF-N-CNTs) }\end{array}$ & NASICON & $1 \mathrm{M} \mathrm{NaCF}_{3} \mathrm{SO}_{3} / \mathrm{TEGDME}$ & $0.1 \mathrm{~mA} \cdot \mathrm{cm}^{-2}$ & 35 & 0.3 & 87 & [67] \\
\hline Carbon & $\mathrm{Pt} / \mathrm{C}$ (Platinum on carbon) & NASICON & $1 \mathrm{M} \mathrm{NaCF} \mathrm{SO}_{3} / \mathrm{TEGDME}$ & $0.1 \mathrm{~mA} \cdot \mathrm{cm}^{-2}$ & - & 0.5 & & [67] \\
\hline Carbon & Ruthenium oxide $\left(\mathrm{RuO}_{2}\right)$ & NASICON & $1 \mathrm{M} \mathrm{NaCF} \mathrm{SO}_{3} / \mathrm{TEGDME}$ & $0.1 \mathrm{~mA} \cdot \mathrm{cm}^{-2}$ & - & 0.5 & & [67] \\
\hline CNT & $\begin{array}{l}\text { Co-CNTs (Cobalt on carbon } \\
\text { nanotubes) }\end{array}$ & NASICON & $1 \mathrm{M} \mathrm{NaCF}_{3} \mathrm{SO}_{3} / \mathrm{TEGDME}$ & $0.1 \mathrm{~mA} \cdot \mathrm{cm}^{-2}$ & - & 0.67 & & [67] \\
\hline $\begin{array}{c}\mathrm{N}-\mathrm{CNTS} \text { (nitrogen-doped carbon } \\
\text { nanotubes) }\end{array}$ & & NASICON & $1 \mathrm{M} \mathrm{NaCF}_{3} \mathrm{SO}_{3} / \mathrm{TEGDME}$ & $0.1 \mathrm{~mA} \cdot \mathrm{cm}^{-2}$ & - & 0.77 & & [67] \\
\hline $\begin{array}{l}\text { Multi-walled carbon nanotubes } \\
\text { (MWCNTs) }\end{array}$ & & NASICON & $1 \mathrm{M} \mathrm{NaCF}{ }_{3} \mathrm{SO}_{3} / \mathrm{TEGDME}$ & $0.1 \mathrm{~mA} \cdot \mathrm{cm}^{-2}$ & - & 0.9 & & [67] \\
\hline Carbon paper & & NASICON & $1 \mathrm{M} \mathrm{NaCF} \mathrm{SO}_{3} / \mathrm{TEGDME}$ & $0.1 \mathrm{~mA} \cdot \mathrm{cm}^{-2}$ & - & 1.18 & & [67] \\
\hline $\begin{array}{c}\mathrm{Ti}_{2} \mathrm{Rh}_{2} \mathrm{O}_{7}(90 \mathrm{wt} \%) \text { with } \\
\text { polyvinylidene fluoride }(10 \mathrm{wt} \%) \\
\text { binder on Teflon-treated carbon } \\
\text { paper }\end{array}$ & $\begin{array}{l}\text { Single crystalline thallium rhodium } \\
\text { pyrochlore oxide (T12Rh2O7) as a } \\
\text { highly efficient bifunctional } \\
\text { electrocatalyst }\end{array}$ & NASICON & $1 \mathrm{M} \mathrm{NaCF}_{3} \mathrm{SO}_{3} / \mathrm{TEGDME}$ & $120 \mathrm{~mA} \cdot \mathrm{g}^{-1}$ & 50 & 0.208 & 93.65 & [68] \\
\hline $\mathrm{CNT} @ \mathrm{Co}_{3} \mathrm{O}_{4}$ or $\mathrm{CNT} / \mathrm{Co}_{3} \mathrm{O}_{4}$ & $\begin{array}{c}\mathrm{Co}_{3} \mathrm{O}_{4} \text { is decorated on carbon } \\
\text { nanotubes by ALD }\left(\mathrm{CNT@Co} \mathrm{O}_{3}\right)\end{array}$ & $\begin{array}{c}\text { Polypropylene } \\
(\mathrm{PP}) \text {-based polymer }\end{array}$ & $\begin{array}{l}\mathrm{NaCF}_{3} \mathrm{SO}_{3} / \text { diethylene glycol } \\
\text { dimethyl ether (DEGDME) }\end{array}$ & $150 \mathrm{~mA} \cdot \mathrm{g}^{-1}$ & $13-14$ & 0.4 & & [63] \\
\hline $\mathrm{Co}_{3} \mathrm{O}_{4}$ nanowires/C & $\begin{array}{l}\text { Heterogeneous catalysts with } \mathrm{Co}_{3} \mathrm{O}_{4} \\
\text { and liquid redox mediators }\end{array}$ & & $\begin{array}{c}\text { Ferrocene added to } 0.05 \mathrm{M} \\
\mathrm{Fe}\left(\mathrm{C}_{5} \mathrm{H}_{5}\right)_{2} \text { in } 1 \mathrm{M} \\
\mathrm{NaClO}_{4} / 1,2 \text {-dimethoxyethane } \\
\text { (DME) }\end{array}$ & $500 \mathrm{~mA} \cdot \mathrm{g}^{-1}$ & 570 & 0.6 & & [69] \\
\hline $\begin{array}{l}\mathrm{MnCo}_{2} \mathrm{O}_{4} / \mathrm{C} \text { air electrode with } \\
\mathrm{MnCo}_{2} \mathrm{O}_{4} \text {, Super P and PVDF }\end{array}$ & $\begin{array}{l}\text { Nanosized porous } \mathrm{MnCo}_{2} \mathrm{O}_{4} \\
\text { microspheres }\end{array}$ & Glass fiber & $\begin{array}{l}1.0 \mathrm{M} \mathrm{NaClO}_{4} \text { in propylene } \\
\text { carbonate (PC) }\end{array}$ & $0.1 \mathrm{~mA} \mathrm{~cm}^{-2}$ & 130 & 1.7 & & {$[70]$} \\
\hline $\begin{array}{l}\text { Carbon black with nickel } \\
\text { nanoparticle catalysts }\end{array}$ & $\begin{array}{l}\text { Air electrode containing nickel } \\
\text { nanoparticles as catalysts }\end{array}$ & $\begin{array}{l}\text { Solid conductor with } \\
\mathrm{Na}_{3} \mathrm{Zr}_{2} \mathrm{Si}_{2} \mathrm{PO}_{12}\end{array}$ & $\begin{array}{l}1 \mathrm{M} \mathrm{NaClO}_{4} \text { in EC/DMC (1:1) with } \\
1 \mathrm{vol} \% \text { of fluoroethylene carbonate } \\
\text { as anolyte, } 1 \mathrm{M} \mathrm{NaOH} \text { as catholyte }\end{array}$ & $0.1 \mathrm{~mA} \mathrm{~cm}^{-2}$ & 100 & 0.57 & & [65] \\
\hline
\end{tabular}


Table 2. Cont

\begin{tabular}{|c|c|c|c|c|c|c|c|c|}
\hline Cathode & Catalyst & Separator & Electrolyte & Current Density & Cycles & Over-Potential (V) & $\begin{array}{l}\text { Round Trip } \\
\text { Efficiency (\%) }\end{array}$ & Ref \\
\hline $\begin{array}{l}\text { Porous cobalt manganese oxide } \\
\text { (CMO) nanocubes CMO } \\
\text { nanoparticles, carbon black } \\
\text { Super-P and PVDF }\end{array}$ & $\begin{array}{c}\text { Spinel-type porous cobalt } \\
\text { manganese oxide }\left(\mathrm{Co}_{\mathrm{x}} \mathrm{Mn}_{3-\mathrm{x}} \mathrm{O}_{4}\right. \\
\mathrm{CMO} \text { ) nanocubes as a } \\
\text { noble-metal-free electrocatalyst }\end{array}$ & $\begin{array}{l}\text { NASICON ceramic } \\
\text { electrolyteused as } \\
\text { Nat ion conductive } \\
\text { membrane to } \\
\text { separate the anode } \\
\text { from the cathode }\end{array}$ & $\begin{array}{l}\text { NASICON ceramic electrolytes; } \\
1 \mathrm{M} \mathrm{NaCF}_{3} \mathrm{SO}_{3} \text { in TEGDME }\end{array}$ & $0.01 \mathrm{~mA} \mathrm{~cm}^{-2}$ & 100 & 0.53 & $\sim 85 \%$ & [71] \\
\hline $\begin{array}{l}\text { Cobalt phosphate, conductive } \\
\text { carbon black Super-P, PVDF }\end{array}$ & $\mathrm{Co}_{3}\left(\mathrm{PO}_{4}\right)_{2}$ nanostructure & NASICON separator & $\begin{array}{l}1 \mathrm{M} \mathrm{NaCF}_{3} \mathrm{SO}_{3} \text { in tetra ethylene } \\
\text { glycol dimethyl ether }\end{array}$ & $0.01 \mathrm{~mA} \mathrm{~cm}^{-2}$ & 50 & 0.23 & $\sim 93 \%$ & [51] \\
\hline Mesoporous carbon & $\begin{array}{l}\text { Graphitic nanoshell/mesoporous } \\
\text { carbon (GNS/MC) nanohybrids }\end{array}$ & $\begin{array}{l}\text { Na super ionic } \\
\text { conducting } \\
\text { (NASICON) solid } \\
\text { electrolyte }\end{array}$ & $\begin{array}{c}1.0 \mathrm{M} \mathrm{NaCF}_{3} \mathrm{SO}_{3} / \mathrm{TEGDME} \\
\text { (nonaqueous electrolyte) and } \\
0.1 \mathrm{M} \mathrm{NaOH} \text { aqueous solution as } \\
\text { an anolyte and a catholyte } \\
\text { respectively }\end{array}$ & $60 \mathrm{~mA}^{-\mathrm{g}^{-1}}$ & 10 & 0.115 & 96.28 & [72] \\
\hline $\mathrm{Pt} / \mathrm{C}$ (Platinum on carbon) & & $\begin{array}{l}\text { Na super ionic } \\
\text { conducting } \\
\text { (NASICON) solid } \\
\text { electrolyte }\end{array}$ & $\begin{array}{c}1.0 \mathrm{M} \mathrm{NaCF}_{3} \mathrm{SO}_{3} / \mathrm{TEGDME} \\
\text { (nonaqueous electrolyte) and } \\
0.1 \mathrm{M} \mathrm{NaOH} \text { aqueous solution } \\
\text { were used as an anolyte and a } \\
\text { catholyte }\end{array}$ & $60 \mathrm{mA.g}^{-1}$ & - & 0.179 & 94.41 & [72] \\
\hline $\mathrm{Ir} / \mathrm{C}$ & & $\begin{array}{l}\text { Na super ionic } \\
\text { conducting } \\
\text { (NASICON) solid } \\
\text { electrolyte }\end{array}$ & $\begin{array}{c}1.0 \mathrm{M} \mathrm{NaCF}_{3} \mathrm{SO}_{3} / \mathrm{TEGDME} \\
\text { (nonaqueous electrolyte) and } \\
0.1 \mathrm{M} \mathrm{NaOH} \text { aqueous solution } \\
\text { were used as an anolyte and a } \\
\text { catholyte }\end{array}$ & $60 \mathrm{~mA} \cdot \mathrm{g}^{-1}$ & & 0.364 & 88.77 & [72] \\
\hline Carbon paper w/o catalyst & N/A & $\begin{array}{l}\text { Na super ionic } \\
\text { conducting } \\
\text { (NASICON) solid } \\
\text { electrolyte }\end{array}$ & $\begin{array}{c}1.0 \mathrm{M} \mathrm{NaCF}_{3} \mathrm{SO}_{3} / \mathrm{TEGDME} \\
\text { (nonaqueous electrolyte) and } \\
0.1 \mathrm{M} \mathrm{NaOH} \text { aqueous solution } \\
\text { were used as an anolyte and a } \\
\text { catholyte }\end{array}$ & $60 \mathrm{~mA} \cdot \mathrm{g}^{-1}$ & & 0.698 & 79.47 & [72] \\
\hline $\begin{array}{l}\text { Highly graphitic nanoshells } \\
\text { embedded in mesoporous } \\
\text { carbon (GNS/MC) sprayed on } \\
\text { Teflon-treated carbon paper used } \\
\text { as the gas diffusion layer }\end{array}$ & $\begin{array}{l}\text { Highly graphitic nanoshells } \\
\text { embedded in mesoporous carbon } \\
\text { (GNS/MC) }\end{array}$ & NASICON & $1.0 \mathrm{M} \mathrm{NaCF}_{3} \mathrm{SO}_{3} / \mathrm{TEGDME}$ & $0.01 \mathrm{~mA} \cdot \mathrm{cm}^{-2}$ & 10 & 0.72 & & [72] \\
\hline Vulcan XC72R & $\mathrm{N} / \mathrm{A}$ & NASICON & $3 \mathrm{M} \mathrm{NaCF}_{3} \mathrm{SO}_{3} / \mathrm{TEGDME}$ & $0.01 \mathrm{~mA} . \mathrm{cm}^{-2}$ & 18 & $\sim 0.6$ & 78 & [55] \\
\hline $\mathrm{Pt} / \mathrm{C}$-coated carbon paper & $\mathrm{Pt} / \mathrm{C}$ & NASICON & $3 \mathrm{M} \mathrm{NaCF}_{3} \mathrm{SO}_{3} / \mathrm{TEGDME}$ & $0.01 \mathrm{~mA} \cdot \mathrm{cm}^{-2}$ & 18 & $\sim 0.4$ & 72.4 & [55] \\
\hline $\begin{array}{l}\text { Nanoporous gold (NPG) air } \\
\text { electrode }\end{array}$ & - & NASICON & $\begin{array}{c}1 \mathrm{M} \mathrm{NaClO}_{4} \text { and } 1 \mathrm{vol} \% \\
\text { fluoroethylene carbonate as an } \\
\text { additive in EC/DMC with a ratio of } \\
1: 1 \text { for the organic electrolyte. } \\
1 \mathrm{M} \mathrm{NaOH} \text { solution as aqueous } \\
\text { electrolyte. }\end{array}$ & $0.5 \mathrm{~mA} \mathrm{~cm}^{-2}$ & $\sim 10$ & $\sim 1.0$ & & [57] \\
\hline
\end{tabular}


Table 2. Cont

\begin{tabular}{|c|c|c|c|c|c|c|c|c|}
\hline Cathode & Catalyst & Separator & Electrolyte & Current Density & Cycles & Over-Potential (V) & $\begin{array}{c}\text { Round Trip } \\
\text { Efficiency (\%) }\end{array}$ & Ref \\
\hline $\begin{array}{l}\text { Carbon nanotube }(\mathrm{CNT}) @ \mathrm{Ni} \\
\text { electrode }\end{array}$ & N/A & NASICON & $\mathrm{NaPF}_{6} / \mathrm{DME}$ electrolyte & $200 \mathrm{~mA} \cdot \mathrm{g}^{-1}$ & $\begin{array}{l}10 \text { cycles at cutoff } \\
\text { capacity of } \\
1200 \mathrm{mAh} \cdot \mathrm{g}^{-1}\end{array}$ & $\sim 1.8$ & & [73] \\
\hline $\begin{array}{l}\text { Self-stacked nitrogen-doped } \\
\text { carbon nanotubes (ncnts) on } \\
\text { commercial porous } \\
\text { polypropylene substrates }\end{array}$ & N/A & Celgard3501 & $\begin{array}{c}0.5 \mathrm{M} \text { sodium triflate }\left(\mathrm{NaSO}_{3} \mathrm{CF}_{3}\right) \\
\text { dissolved in DEGDME }\end{array}$ & $75 \mathrm{~mA}^{-\mathrm{g}^{-1}}$ & $\begin{array}{l}10 \text { cycles at cutoff } \\
\text { capacity of } \\
300 \mathrm{mAh} \cdot \mathrm{g}^{-1}\end{array}$ & $\sim 2.0$ & & [74] \\
\hline \multirow[t]{2}{*}{ CNT/Ni foam } & N/A & & $\begin{array}{c}1.0 \mathrm{M} \mathrm{NaClO}_{4} \text { in } \\
\text { 1,2-dimethoxyethane (DME) }\end{array}$ & $150 \mathrm{~mA} \cdot \mathrm{g}^{-1}$ & 3 & 1.2 & & [75] \\
\hline & N/A & - & $\begin{array}{l}0.5 \mathrm{M} \text { solutions of } \mathrm{NaCF}_{3} \mathrm{SO}_{3} \text { in } \\
\text { DEGDME, TEGDME, and DME as } \\
\text { ether-based electrolytes }\end{array}$ & $100 \mathrm{~mA}^{-\mathrm{g}^{-1}}$ & $\begin{array}{l}20 \text { cycles at cutoff } \\
\text { capacity of } \\
500 \mathrm{mAh}^{-1}\end{array}$ & $\sim 1.8$ & - & [76] \\
\hline $\begin{array}{l}\mathrm{NiCo}_{2} \mathrm{O}_{4} \text { nanosheets were } \\
\text { directly deposited on the } \mathrm{Ni} \\
\text { foam }\end{array}$ & N/A & - & $\begin{array}{l}0.05 \mathrm{M} \mathrm{NaI} \text { containing DME } \\
\text { (1.2-dimethoxyethane) electrolyte }\end{array}$ & $500 \mathrm{~mA} \cdot \mathrm{g}^{-1}$ & $\begin{array}{l}150 \text { cycles with a } \\
\text { capacity limit of } \\
1000 \text { mA.h.g }{ }^{-1}\end{array}$ & $\sim 0.8$ & - & [77] \\
\hline $\begin{array}{l}\text { Nitrogen-doped graphene } \\
\text { nanosheets (N-GNs) displayed }\end{array}$ & N/A & Celgard 3501 & $\begin{array}{l}0.5 \mathrm{M} \text { sodium triflate }\left(\mathrm{NaSO}_{3} \mathrm{CF}_{3}\right) \\
\text { dissolved in diethylene glycol } \\
\text { diethyl ether (DEGDME) }\end{array}$ & $130 \mathrm{~mA} \cdot \mathrm{g}^{-1}$ & 10 & - & - & [78] \\
\hline Graphene nanosheets & N/A & - & $\begin{array}{c}0.05 \mathrm{M} \mathrm{Fe}\left(\mathrm{C}_{5} \mathrm{H}_{5}\right)_{2} \text {-containing } \\
\text { electrolyte in } 1.0 \mathrm{M} \mathrm{NaClO}_{4} \text { in a } \\
\text { nonaqueous solution of } \\
\text { 1,2-dimethoxyethane (DME) }\end{array}$ & $500 \mathrm{~mA} \cdot \mathrm{g}^{-1}$ & $\begin{array}{l}230 \text { cycles with a high } \\
\text { capacity of } \\
1000 \mathrm{~mA} \cdot \mathrm{h} \cdot \mathrm{g}^{-1}\end{array}$ & $\sim 1.0$ & - & [79] \\
\hline Carbon black on $\mathrm{Al}$ mesh & & Glass fiber separator & $\begin{array}{c}1 \mathrm{M} \text { solutions of NaTFSI in } \\
\text { propylene carbonate (PC) } \\
\text { electrolyte }\end{array}$ & $200 \mathrm{~mA} \cdot \mathrm{g}^{-1}$ & $\begin{array}{l}20 \text { cycles at cutoff of } \\
800 \mathrm{mAh} \cdot \mathrm{g}^{-1}\end{array}$ & - & 47 & [80] \\
\hline $\begin{array}{c}\text { Carambola-shaped vanadium } \\
\text { oxide }\left(\mathrm{VO}_{2}\right) \text { nanostructures on } \\
\text { carbon paper }\end{array}$ & Vanadium oxide $\left(\mathrm{VO}_{2}\right)$ & NASICON & $1 \mathrm{M} \mathrm{NaCF}_{3} \mathrm{SO}_{3}$ in TEGDME & $4 \mathrm{~mA} \cdot \mathrm{g}^{-1}$ & 50 & 0.64 & 81 & [81] \\
\hline Porous $\mathrm{CaMnO}_{3} / \mathrm{C}$ & $\begin{array}{l}\text { Calcium-manganese oxide } \\
\text { microspheres }\end{array}$ & NASICON & $\mathrm{NaSO}_{3} \mathrm{CF}_{3} / \mathrm{TEGDME}$ & $100 \mathrm{~mA} \mathrm{~g}^{-1}$ & $\begin{array}{l}80 \text { cycles at cut off of } \\
1000 \mathrm{mAh} \cdot \mathrm{g}^{-1}\end{array}$ & $\sim 1.0$ & 55 & [82] \\
\hline $\begin{array}{l}\text { Urchin-shaped } \mathrm{MnO}_{2} \text { on the } \\
\text { RGO-coated carbon microfiber }\end{array}$ & Urchin-shaped $\mathrm{MnO}_{2}$ on $\mathrm{RGO}$ & NASICON & $\begin{array}{l}0.1 \mathrm{M} \mathrm{NaOH}_{\text {aqueous catholyte. }} \\
\mathrm{NaCF}_{3} \mathrm{SO}_{3} \text { in TEGDME as anolyte }\end{array}$ & $15 \mathrm{~mA} \cdot \mathrm{g}^{-1}$ & 20 & 0.7 & 81 & [83] \\
\hline Pt@graphene nanosheets & Platinum & NASICON & $1 \mathrm{M} \mathrm{NaClO}_{4} / \mathrm{PC}$ & $0.1 \mathrm{~mA} \cdot \mathrm{cm}^{-2}$ & $\begin{array}{l}10 \text { cycles at a cut off of } \\
1000 \mathrm{mAh} \cdot \mathrm{g}^{-1}\end{array}$ & $\sim 1.5$ & 68 & [84] \\
\hline
\end{tabular}




\section{Conclusions}

Although sodium-ion batteries are promising candidates for energy storage purposes, they still suffer from limited cyclability and are under development. The main purpose of this article was to summarize the work done in RT Na-S and Na-air/ $\mathrm{O}_{2}$ batteries to implement the technology in application. However, technology is still in its infancy and much more research is needed to overcome the major hurdles like poor capacity retention and cycle life because of the poor conductivity and polysulfide formation of sodium during cycling. Newer sodium ion-conducting separator may be considered to improve the battery performance further. Modification or synthesis of novel catalysts should also be considered to suppress the sodium dendrite formation that eventually results in battery death. By addressing these issues, better batteries can be developed for use in automobiles and other electronic devices.

Author Contributions: N.C. and M.S. have contributed equally to the review paper.

Funding: This research received no external funding.

Conflicts of Interest: The authors declare no conflict of interest.

\section{References}

1. Goodenough, J.B. Evolution of Strategies for Modern Rechargeable Batteries. Acc. Chem. Res. 2012, 46, $1053-1061$. [CrossRef] [PubMed]

2. Etacheri, V.; Marom, R.; Elazari, R.; Salitra, G.; Aurbach, D. Challenges in the Development of Advanced Li-Ion Batteries: A Review. Energy Environ. Sci. 2011, 4, 3243-3262. [CrossRef]

3. Scrosati, B.; Garche, J. Lithium Batteries: Status, Prospects and Future. J. Power Sources 2010, 195, $2419-2430$. [CrossRef]

4. Manthiram, A. Materials Challenges and Opportunities of Lithium Ion Batteries. J. Phys. Chem. Lett. 2011, 2, 176-184. [CrossRef]

5. Albertus, P.; Babinec, S.; Litzelman, S.; Newman, A. Status and Challenges in Enabling the Lithium Metal Electrode for High-Energy and Low-Cost Rechargeable Batteries. Nat. Energy 2017, 3, 16-21. [CrossRef]

6. McCloskey, B.D. Attainable Gravimetric and Volumetric Energy Density of Li-S and Li Ion Battery Cells with Solid Separator-Protected Li Metal Anodes. J. Phys. Chem. Lett. 2015, 6, 4581-4588. [CrossRef]

7. Park, C.W.; Ahn, J.H.; Ryu, H.S.; Kim, K.W.; Ahn, H.J. Room-Temperature Solid-State Sodium/Sulfur Battery. Electrochem. Solid State Lett. 2006, 9, A123-A125. [CrossRef]

8. Yu, X.; Manthiram, A. Capacity Enhancement and Discharge Mechanisms of Room-Temperature Sodium-Sulfur Batteries. ChemElectroChem 2014, 1, 1275-1280. [CrossRef]

9. Zhang, B.; Lai, W.; Xu, Y.; Wang, Y.X.; Chou, S.L.; Liu, H.K.; Dou, S.X.; Wang, Y.; Chou, S.; Liu, H.; et al. Room-Temperature Sodium-Sulfur Batteries: A Comprehensive Review on Research Progress and Cell Chemistry. Adv. Energy Mater. 2017, 7, 1602829.

10. Manthiram, A.; Yu, X. Ambient Temperature Sodium-Sulfur Batteries. Small 2015, 11, 2108-2114. [CrossRef]

11. Xu, X.; Zhou, D.; Qin, X.; Lin, K.; Kang, F.; Li, B.; Shanmukaraj, D.; Rojo, T.; Armand, M.; Wang, G. A RoomTemperature Sodium-Sulfur Battery with High Capacity and Stable Cycling Performance. Nat. Commun. 2018, 9, 3870. [CrossRef] [PubMed]

12. Wang, J.; Yang, J.; Nuli, Y.; Holze, R. Room Temperature Na/S Batteries with Sulfur Composite Cathode Materials. Electrochem. Commun. 2007, 9, 31-34. [CrossRef]

13. Kim, J.S.; Ahn, H.J.; Kim, I.P.; Kim, K.W.; Ahn, J.H.; Park, C.W.; Ryu, H.S. The Short-Term Cycling Properties of Na/PVdF/S Battery at Ambient Temperature. J. Solid State Electrochem. 2008, 12, 861-865. [CrossRef]

14. Park, C.W.; Ryu, H.S.; Kim, K.W.; Ahn, J.H.; Lee, J.Y.; Ahn, H.J. Discharge Properties of All-Solid Sodium-Sulfur Battery Using Poly (Ethylene Oxide) Electrolyte. J. Power Sources 2007, 165, 450-454. [CrossRef]

15. Wenzel, S.; Metelmann, H.; Raiis, C.; Durr, A.K.; Janek, J.; Adelhelm, P. Thermodynamics and Cell Chemistry of Room Temperature Sodium/Sulfur Cells with Liquid and Liquid/Solid Electrolyte. J. Power Sources 2013, 243, 758-765. [CrossRef]

16. Kim, I.; Kim, C.H.; Choi, S.H.; Ahn, J.P.; Ahn, J.H.; Kim, K.W.; Cairns, E.J.; Ahn, H.J. A Singular Flexible Cathode for Room Temperature Sodium/Sulfur Battery. J. Power Sources 2016, 307, 31-37. [CrossRef] 
17. Yu, X.; Manthiram, A. Sodium-Sulfur Batteries with a Polymer-Coated NASICON-Type Sodium-Ion Solid Electrolyte. Matter 2019, 1, 439-451. [CrossRef]

18. Wu, J.; Liu, J.; Lu, Z.; Lin, K.; Lyu, Y.Q.; Li, B.; Ciucci, F.; Kim, J.K. Non-Flammable Electrolyte for Dendrite-Free Sodium-Sulfur Battery. Energy Storage Mater. 2019. [CrossRef]

19. Hwang, T.H.; Jung, D.S.; Kim, J.S.; Kim, B.G.; Choi, J.W. One-Dimensional Carbon-Sulfur Composite Fibers for Na-S Rechargeable Batteries Operating at Room Temperature. Nano Lett. 2013, 13, 4532-4538. [CrossRef]

20. Zhang, B.W.; Sheng, T.; Liu, Y.D.; Wang, Y.X.; Zhang, L.; Lai, W.H.; Wang, L.; Yang, J.; Gu, Q.F.; Chou, S.L.; et al. Atomic Cobalt as an Efficient Electrocatalyst in Sulfur Cathodes for Superior Room-Temperature Sodium-Sulfur Batteries. Nat. Commun. 2018, 9, 4082. [CrossRef]

21. Lu, Q.; Wang, X.; Cao, J.; Chen, C.; Chen, K.; Zhao, Z.; Niu, Z.; Chen, J. Freestanding Carbon Fiber Cloth/Sulfur Composites for Flexible Room-Temperature Sodium-Sulfur Batteries. Energy Storage Mater. 2017, 8, 77-84. [CrossRef]

22. Ghosh, A.; Kumar, A.; Roy, A.; Panda, M.R.; Kar, M.; Macfarlane, D.R.; Mitra, S. Three-Dimensionally Reinforced Freestanding Cathode for High-Energy Room-Temperature Sodium-Sulfur Batteries. ACS Appl. Mater. Interfaces 2019, 11, 14101-14109. [CrossRef] [PubMed]

23. Xin, S.; Gu, L.; Zhao, N.H.; Yin, Y.X.; Zhou, L.J.; Guo, Y.G.; Wan, L.J. Smaller Sulfur Molecules Promise Better Lithium-Sulfur Batteries. J. Am. Chem. Soc. 2012, 134, 18510-18513. [CrossRef] [PubMed]

24. Lee, D.J.; Park, J.W.; Hasa, I.; Sun, Y.K.; Scrosati, B.; Hassoun, J. Alternative Materials for Sodium Ion-Sulphur Batteries. J. Mater. Chem. A 2013, 1, 5256. [CrossRef]

25. Wang, Y.X.; Yang, J.; Lai, W.; Chou, S.L.; Gu, Q.F.; Liu, H.K.; Zhao, D.; Dou, S.X. Achieving High-Performance Room-Temperature Sodium-Sulfur Batteries With S@Interconnected Mesoporous Carbon Hollow Nanospheres. J. Am. Chem. Soc. 2016, 138, 16576-16579. [CrossRef]

26. Zheng, S.; Wen, Y.; Zhu, Y.; Han, Z.; Wang, J.; Yang, J.; Wang, C. In Situ Sulfur Reduction and Intercalation of Graphite Oxides for Li-S Battery Cathodes. Adv. Energy Mater. 2014, 4, 1400482. [CrossRef]

27. Wei, S.; Xu, S.; Agrawral, A.; Choudhury, S.; Lu, Y.; Tu, Z.; Ma, L.; Archer, L.A. A Stable Room-Temperature Sodium-Sulfur Battery. Nat. Commun. 2016, 7, 11722. [CrossRef]

28. Zhang, S.S.; Zhang, S. Role of $\mathrm{LiNO}_{3}$ in Rechargeable Lithium/Sulfur Battery. Electrochim. Acta 2012, 70, 344-348. [CrossRef]

29. Safa, M.; Hao, Y.; Chamaani, A.; Adelowo, E.; Chawla, N.; Wang, C.; El Zahab, B. Capacity Fading Mechanism in Lithium-Sulfur Battery Using Poly(Ionic Liquid) Gel Electrolyte. Electrochim. Acta 2017, 258, 1284-1292. [CrossRef]

30. Safa, M.; Adelowo, E.; Chamaani, A.; Chawla, N.; Baboukani, A.R.; Herndon, M.; Wang, C.; El Zahab, B. Poly(Ionic Liquid)-Based Composite Gel Electrolyte for Lithium Batteries. ChemElectroChem 2019, 6, 3319-3326. [CrossRef]

31. Safa, M.; Chamaani, A.; Chawla, N.; El Zahab, B. Polymeric Ionic Liquid Gel Electrolyte for Room Temperature Lithium Battery Applications. Electrochim. Acta 2016, 213, 587-593. [CrossRef]

32. $\mathrm{Xu}, \mathrm{K}$. Electrolytes and Interphases in Li-Ion Batteries and Beyond. Chem. Rev. 2014, 114, 11503-11618. [CrossRef] [PubMed]

33. Kalhoff, J.; Eshetu, G.G.; Bresser, D.; Passerini, S. Safer Electrolytes for Lithium-Ion Batteries: State of the Art and Perspectives. ChemSusChem 2015, 8, 2154-2175. [CrossRef] [PubMed]

34. Seki, S.; Watanabe, M. Polymer and Ionic Liquid Electrolytes for Advanced Lithium Batteries. In Nanoscale Technology for Advanced Lithium Batteries; Springer: Berlin, Germany, 2014; pp. 51-61.

35. Watanabe, M.; Thomas, M.L.; Zhang, S.; Ueno, K.; Yasuda, T.; Dokko, K. Application of Ionic Liquids to Energy Storage and Conversion Materials and Devices. Chem. Rev. 2017, 117, 7190-7239. [CrossRef]

36. Barghamadi, M.; Best, A.S.; Bhatt, A.I.; Hollenkamp, A.F.; Musameh, M.; Rees, R.J.; Ruther, T. Lithium-Sulfur Batteries-The Solution is in the Electrolyte, but is the Electrolyte a Solution? Energy Environ. Sci. 2014, 7, 3902-3920. [CrossRef]

37. Li, G.; Li, Z.; Zhang, B.; Lin, Z. Developments of Electrolyte Systems for Lithium-Sulfur Batteries: A Review. Energy Storage 2015, 3, 5.

38. Yuan, L.; Feng, J.; Ai, X.; Cao, Y.; Chen, S.; Yang, H. Improved Dischargeability and Reversibility of Sulfur Cathode in a Novel Ionic Liquid Electrolyte. Electrochem. Commun. 2006, 8, 610-614. [CrossRef]

39. Chamaani, A.; Safa, M.; Chawla, N.; El Zahab, B. Composite Gel Polymer Electrolyte for Improved Cyclability in Lithium-Oxygen Batteries. ACS Appl. Mater. Interfaces 2017, 9, 33819-33826. [CrossRef] 
40. Chawla, N.; Bharti, N.; Singh, S. Recent advances in non-flammable electrolytes for safer lithium-ion batteries. Batteries 2019, 5, 19.

41. Chawla, N. Nanocatalysts in Lithium Oxygen Batteries. Nano Sci. Nano Technol. An Indian J. 2018, 12, 128.

42. Chawla, N.; Chamaani, A.; Safa, M.; El Zahab, B. Palladium-Filled Carbon Nanotubes Cathode for Improved Electrolyte Stability and Cyclability Performance of $\mathrm{Li}^{-} \mathrm{O}_{2}$ Batteries. J. Electrochem. Soc. 2017, 164, A6303-A6307. [CrossRef]

43. Chawla, N.; Chamaani, A.; Safa, M.; Herndon, M.; El Zahab, B. Mechanism of Ionic Impedance Growth for Palladium-Containing CNT Electrodes in Lithium-Oxygen Battery Electrodes and its Contribution to Battery Failure. Batteries 2019, 5, 15. [CrossRef]

44. Viswanathan, V.; GirishKumar, G.; McCloskey, B.D.; Hummelshoj, J.S.; Norskov, J.K.; Thygesen, K.S.; Luntz, A.C. Electrical Conductivity in $\mathrm{Li}_{2} \mathrm{O}_{2}$ and its Role in Determining Capacity Limitations in Non-Aqueous Li-O ${ }_{2}$ Batteries. J. Chem. Phys. 2011, 135, 214704. [CrossRef] [PubMed]

45. GirishKumar, G.; McCloskey, B.; Luntz, A.C.; Swanson, S.; Wilcke, W. Lithium-Air Battery: Promise and Challenges. J. Phys. Chem. Lett. 2010, 1, 2193-2203. [CrossRef]

46. Ogasawara, T.; Debart, A.; Holzapfel, M.; Novak, P.; Bruce, P.G. Rechargeable $\mathrm{Li}_{2} \mathrm{O}_{2}$ Electrode for Lithium Batteries. J. Am. Chem. Soc. 2006, 37, 1390-1393. [CrossRef]

47. Chawla, N. Recent Advances in Air-Battery Chemistries. Mater. Today Chem. 2019, 12, 324-331. [CrossRef]

48. Yin, W.W.; Fu, Z.W. The Potential of Na-Air Batteries. ChemCatChem 2017, 9, 1545-1553. [CrossRef]

49. Peled, E.; Golodnitsky, D.; Mazor, H.; Goor, M.; Avshalomov, S. Parameter Analysis of a Practical Lithiumand Sodium-Air Electric Vehicle Battery. J. Power Sources 2011, 196, 6835-6840. [CrossRef]

50. Sun, Q.; Yang, Y.; Fu, Z.W. Electrochemical Properties of Room Temperature Sodium-Air Batteries with Non-Aqueous Electrolyte. Electrochem. Commun. 2012, 16, 22-25. [CrossRef]

51. Senthilkumar, B.; Khan, Z.; Park, S.; Seo, I.; Ko, H.; Kim, Y. Exploration of Cobalt Phosphate as a Potential Catalyst for Rechargeable Aqueous Sodium-Air Battery. J. Power Sources 2016, 311, 29-34. [CrossRef]

52. Liang, F.; Qiu, X.; Zhang, Q.; Kang, Y.; Koo, A.; Hayashi, K.; Chen, K.; Xue, D.; Hui, K.N.; Yadegari, H.; et al. A Liquid Anode for Rechargeable Sodium-Air Batteries with Low Voltage Gap and High Safety. Nano Energy 2018, 49, 574-579. [CrossRef]

53. Zhao, Y.; Goncharova, L.V.; Zhang, Q.; Kaghazchi, P.; Sun, Q.; Lushington, A.; Wang, B.; Li, R.; Sun, X. Inorganic-Organic Coating Via Molecular Layer Deposition Enables Long Life Sodium Metal Anode. Nano Lett. 2017, 17, 5653-5659. [CrossRef] [PubMed]

54. Yu, J.; Hu, Y.S.; Pan, F.; Zhang, Z.; Wang, Q.; Li, H.; Huang, X.; Chen, L. A Class of Liquid Anode for Rechargeable Batteries with Ultralong Cycle Life. Nat. Commun. 2017, 8, 14629. [CrossRef] [PubMed]

55. Sahgong, S.H.; Senthilkumar, S.; Kim, K.; Hwang, S.M.; Kim, Y. Rechargeable Aqueous Na-Air Batteries: Highly Improved Voltage Efficiency by Use of Catalysts. Electrochem. Commun. 2015, 61, 53-56. [CrossRef]

56. Faktorovich Simon, E.; Natan, A.; Peled, E.; Golodnitsky, D. Oxygen Redox Processes in PEGDME-Based Electrolytes for the Na-Air Battery. J. Solid State Electrochem. 2018, 22, 1015-1022. [CrossRef]

57. Hashimoto, T.; Hayashi, K. Aqueous and Nonaqueous Sodium-Air Cells with Nanoporous Gold Cathode. Electrochim. Acta 2015, 182, 809-814. [CrossRef]

58. Kubisiak, P.; Eilmes, A. Molecular Dynamics Simulations of Ionic Liquid Based Electrolytes for Na-Ion Batteries: Effects of Force Field. J. Phys. Chem. B 2017, 121, 9957-9968. [CrossRef]

59. Lutz, L.; Corte, D.A.D.; Tang, M.; Salager, E.; Deschamps, M.; Grimaud, A.; Johnson, L.; Bruce, P.G.; Tarascon, J.M. Role of Electrolyte Anions in the $\mathrm{Na}-\mathrm{O}_{2}$ Battery: Implications for $\mathrm{NaO}_{2}$ Solvation and the Stability of the Sodium Solid Electrolyte Interphase in Glyme Ethers. Chem. Mater. 2017, 29, 6066-6075. [CrossRef]

60. Goodenough, J.B.; Hong, H.Y.P.; Kafalas, J.A. Fast Na+-Ion Transport in Skeleton Structures. Mater. Res. Bull. 1976, 11, 203-220. [CrossRef]

61. Kang, Y.; Zou, D.; Zhang, J.; Liang, F.; Hayashi, K.; Wang, H.; Xue, D.; Chen, K.; Adair, K.R.; Sun, X. Dual-Phase Spinel MnCo 2 O 4 Nanocrystals with Nitrogen-Doped Reduced Graphene Oxide as Potential Catalyst for Hybrid Na-Air Batteries. Electrochim. Acta 2017, 244, 222-229. [CrossRef]

62. Khan, Z.; Parveen, N.; Ali, S.; Senthilkumar, S.T.; Park, S.; Kim, Y.; Hwan, M.; Ko, H. Electrochimica Acta Three-dimensional SnS 2 Nanopetals for Hybrid Sodium-Air Batteries. Electrochim. Acta 2017, 257, 328-334. [CrossRef] 
63. Sun, Q.; Liu, J.; Li, X.; Wang, B.; Yadegari, H.; Lushington, A.; Banis, M.N.; Zhao, Y.; Xiao, W.; Chen, N.; et al. Atomic Layer Deposited Non-Noble Metal Oxide Catalyst for Sodium-Air Batteries: Tuning the Morphologies and Compositions of Discharge Product. Adv. Funct. Mater. 2017, 27, 1606662. [CrossRef]

64. Kim, M.; Ju, H.; Kim, J. Dihydrogen Phosphate Ion Functionalized Nanocrystalline Thallium Ruthenium Oxide Pyrochlore as a Bifunctional Electrocatalyst for Aqueous Na-Air Batteries. Appl. Catal. B Environ. 2019, 245, 29-39. [CrossRef]

65. Su, F.; Qiu, X.; Liang, F.; Tanaka, M.; Qu, T.; Yao, Y.; Ma, W.; Yang, B.; Dai, Y.; Hayashi, K.; et al. Preparation of Nickel Nanoparticles by Direct Current Arc Discharge Method and Their Catalytic Application in Hybrid Na-Air Battery. Nanomaterials 2018, 8, 684. [CrossRef] [PubMed]

66. Kim, M.; Ju, H.; Kim, J. Single Crystalline Bi2Ru2O7 Pyrochlore Oxide Nanoparticles as Efficient Bifunctional Oxygen Electrocatalyst for Hybrid Na-Air Batteries. Chem. Eng. J. 2019, 358, 11-19. [CrossRef]

67. Wu, Y.; Qiu, X.; Liang, F.; Zhang, Q.; Koo, A.; Dai, Y.; Lei, Y.; Sun, X. A Metal-Organic Framework-Derived Bifunctional Catalyst for Hybrid Sodium-Air Batteries. Appl. Catal. B Environ. 2019, 241, 407-414. [CrossRef]

68. Kim, M.; Ju, H.; Kim, J. Single Crystalline Thallium Rhodium Oxide Pyrochlore for Highly Improved Round Trip Efficiency of Hybrid Na-Air Batteries. Dalton Trans. 2018, 47, 15217-15225. [CrossRef]

69. Yin, W.W.; Fu, Z.W. A Highly Efficient Bifunctional Heterogeneous Catalyst for Morphological Control of Discharged Products in Na-Air Batteries. Chem. Commun. 2017, 53, 1522-1525. [CrossRef]

70. Shang, M.; Liu, Y.; Xia, J.; Zhang, S.; Yang, J. Synthesis and Characterization of $\mathrm{MnCo}_{2} \mathrm{O}_{4}$ Microspheres Based Air Electrode for Rechargeable Sodium-Air Batteries. Ceram. Int. 2017, 43, 3218-3223. [CrossRef]

71. Abirami, M.; Hwang, S.M.; Yang, J.; Senthilkumar, S.T.; Kim, J.; Go, W.S.; Senthilkumar, B.; Song, H.K.; Kim, Y. A Metal-Organic Framework Derived Porous Cobalt Manganese Oxide Bifunctional Electrocatalyst for Hybrid Na-Air/Seawater Batteries. ACS Appl. Mater. Interfaces 2016, 8, 32778-32787. [CrossRef]

72. Cheon, J.Y.; Kim, K.; Sa, Y.J.; Sahgong, S.H.; Hong, Y.; Woo, J.; Yim, S.; Jeong, H.Y.; Kim, Y.; Joo, S.H. Graphitic Nanoshell/Mesoporous Carbon Nanohybrids as Highly Efficient and Stable Bifunctional Oxygen Electrocatalysts for Rechargeable Aqueous Na-Air Batteries. Adv. Energy Mater. 2016, 6, 1501794. [CrossRef]

73. Sang, L.; Yin, W.W.; Yue, J.L.; Cao, M.H.; Liu, W.; Ding, J.J.; Fu, Z.W. Dual Catalytic Behavior of a Soluble Ferrocene as an Electrocatalyst and in the Electrochemistry for Na-Air Batteries. J. Mater. Chem. A 2015, 3, 19027-19032.

74. Sun, Q.; Yadegari, H.; Banis, M.N.; Liu, J.; Xiao, B.; Wang, B.; Lawes, S.; Li, X.; Li, R.; Sun, X. Self-Stacked Nitrogen-Doped Carbon Nanotubes as Long-Life Air Electrode for Sodium-Air Batteries: Elucidating the Evolution of Discharge Product Morphology. Nano Energy 2015, 12, 698-708. [CrossRef]

75. Shadike, Z.; Sang, L.; Yin, W.W.; Yang, Y.; Ding, F.; Li, H.; Fu, Z.W. A Long-Life Na-Air Battery Based on a Soluble NaI Catalyst. Chem. Commun. 2015, 51, 2324-2327.

76. Yadegari, H.; Li, Y.; Banis, M.N.; Li, X.; Wang, B.; Sun, Q.; Li, R.; Sham, T.K.; Cui, X.; Sun, X. On Rechargeability and Reaction Kinetics of Sodium-Air Batteries. Energy Environ. Sci. 2014, 7, 3747-3757. [CrossRef]

77. Liu, W.M.; Yin, W.W.; Ding, F.; Sang, L.; Fu, Z.W. NiCo $\mathrm{O}_{4}$ Nanosheets Supported on Ni Foam for Rechargeable Nonaqueous Sodium-Air Batteries. Electrochem. Commun. 2014, 45, 87-90. [CrossRef]

78. Li, Y.; Yadegari, H.; Li, X.; Banis, M.N.; Li, R.; Sun, X. Superior Catalytic Activity of Nitrogen-Doped Graphene Cathodes for High Energy Capacity Sodium-Air Batteries. Chem. Commun. 2013, 49, 11731-11733. [CrossRef]

79. Liu, W.; Sun, Q.; Yang, Y.; Xie, J.Y.; Fu, Z.W. An Enhanced Electrochemical Performance of a Sodium-Air Battery with Graphene Nanosheets as Air Electrode Catalysts. Chem. Commun. 2013, 49, 1951-1953. [CrossRef]

80. Xu, S.; Lu, Y.; Wang, H.; Abruna, H.D.; Archer, L.A. A Rechargeable Na- $\mathrm{CO}_{2} / \mathrm{O}_{2}$ Battery Enabled by Stable Nanoparticle Hybrid Electrolytes. J. Mater. Chem. A 2014, 2, 17723-17729. [CrossRef]

81. Khan, Z.; Senthilkumar, B.; O Park, S.; Park, S.; Yang, J.; Lee, J.H.; Song, H.K.; Kim, Y.; Kwak, S.K.; Ko, H. Carambola-Shaped $\mathrm{VO}_{2}$ Nanostructures: A Binder-Free Air Electrode for an Aqueous Na-Air Battery. J. Mater. Chem. A 2017, 5, 2037-2044. [CrossRef]

82. Hu, Y.; Han, X.; Zhao, Q.; Du, J.; Cheng, F.; Chen, J. Porous Perovskite Calcium-Manganese Oxide Microspheres as an Efficient Catalyst for Rechargeable Sodium-Oxygen batteries. J. Mater. Chem. A 2015, 3, 3320-3324. [CrossRef] 
83. Khan, Z.; Park, S.; Hwang, S.M.; Yang, J.; Lee, Y.; Song, H.K.; Kim, Y.; Ko, H. Hierarchical Urchin-Shaped $\alpha-\mathrm{MnO}_{2}$ on Graphene-Coated Carbon Microfibers: A Binder-Free Electrode for Rechargeable Aqueous Na-Air Battery. NPG Asia Mater. 2016, 8, e294. [CrossRef]

84. Wen, Z.; Rui, K.; Shen, C.; Zhang, S.; Lu, Y.; Yang, J. Graphene Nanosheets Loaded with Pt Nanoparticles with Enhanced Electrochemical Performance for Sodium-Oxygen Batteries. J. Mater. Chem. A 2015, 3, 2568-2571.

(C) 2019 by the authors. Licensee MDPI, Basel, Switzerland. This article is an open access article distributed under the terms and conditions of the Creative Commons Attribution (CC BY) license (http://creativecommons.org/licenses/by/4.0/). 